\title{
Yumuşak Hukuk Tartışmaları Çerçevesinde BM İş Dünyası ve İnsan Hakları Rehber İlkeleri'nin Değerlendirilmesi
}

\author{
Analyzing the UN Guiding Principles on Business and Human Rights \\ (UNGPs) in the Context of Soft Law Debates
}

\section{Cansu Atılgan Pazvantoğlu* (iD}

\section{öz}

Bu çalışmanın amacı, BM İş Dünyası ve İnsan Hakları Rehber İlkeleri’ni, yumuşak hukuk ve sert hukuk ilişkisi çerçevesinde uluslararası hukukta güncelliğini koruyan yumuşak hukuk tartışmaları ve eleştirileri kapsamında değerlendirmek, Rehber İlkeleri’nin güncel durumunu irdeleyerek, var olan etkinliğinin söz konusu tartışmalarla ilişkisini çözümlemektir. Çalışma kapsamında yumuşak hukukun tanım ve kapsamına yer verilmiş, yumuşak hukuka ilişkin tartışmalar sınıflandırılmış ve örneklenmiştir. Uluslararası alanda insan hakları ve iş dünyası alanlarının etkileşiminin ve bununla birlikte yumuşak hukukun önemli bir örneğini oluşturan BM İş Dünyası ve İnsan Hakları Rehber İlkeleri (UNGPs) çalışmanın çözümleme ögesi olarak ele alınmış, Rehber İlkeleri’ne yönelik sert hukuk, yumuşak hukuk ve karma yaklaşımları uluslararası hukuktaki yumuşak hukuk tartışmalarıyla ilişkilendirilmiştir. Tarihsel süreçte insan hakları ve iş dünyası etkileşimi konuya ilişkin BM düzenlemelerinin incelenmesiyle aktarılmış, BM İş Dünyası ve İnsan Hakları Rehber İlkeleri’nin bu süreçteki yeri, güncel COVID 19 krizindeki etkinliği sorgulanarak temellendirilmiştir. Yumuşak hukukun bağlayıcıllı̆ının olmaması ve denetim işleyişinin yokluğu Rehber İlkeleri konusunda en önemli eleştiriler arasında yer alırken bir uluslararası antlaşma yapılabilmesi konusunda da uluslararası bir uzlaşı sağlanamamaktadır. Değerlendirme, BM İş Dünyası ve İnsan Hakları Rehber İlkeleri’nin yumuşak hukuk olarak etkinliğini sürdürmesini, sert hukuka dönüşmesini ya da karma biçimde varlık göstermesini savunan görüşlerle süregiden tartışmalar doğrultusunda yapılmıştır.

Anahtar Kelimeler: Yumuşak Hukuk, Sert Hukuk, BM İş Dünyası ve İnsan Hakları Rehber İlkeleri, COVID 19

* Dr. Öğretim Üyesi, Eskişehir Osmangazi Üniversitesi, Uluslararası İlişkiler Bölümü, Uluslararası Hukuk Ana Bilim Dalı, ORCID: 0000-0002-5404-8064.

Sorumlu Yazar/Correspondence Author: Cansu Atılgan Pazvantoğlu

E-posta/E-mail: cansuatilgan@ogu.edu.tr

Geliş Tarihi/Received: $\quad$ 13.09.2021 Kabul Tarihi/Accepted: $\quad 08.11 .2021$ 


\section{ABSTRACT}

The aim of this study is to analyze the UN Guiding Principles on Business and Human Rights within the scope of current soft law debates, and criticisms in the international law arena considering the relationship between soft law and hard law and scrutinize the relationship of its existing effectiveness with these debates through analyzing the current status of the Guiding Principles. The definition and extent of soft law are covered in the study's scope, as are discussions on soft law are categorized and demonstrated. The UN Guiding Principles on Business and Human Rights (UNGPs), which are outstanding facets of the interaction of human rights and business areas as well as a soft law illustration in the international arena, have been addressed as study's analysis element, and hard law, soft law, and mixed approaches to the Guiding Principles were associated with soft law debates in the international arena. The historical interaction of human rights and the business world has been presented by a review of the relevant UN regulations, and the position of the UN Guiding Principles on Business and Human Rights in this process has been founded upon questioning its effectiveness in the current COVID 19 crisis. While the absence of binding force in soft law and the lack of an audit function are among the most serious criticisms of the Guidelines, there is no international consensus regarding a future global agreement. The study was carried out in light of ongoing debates that highlight various advocacy points, such as whether the UN Guiding Principles on Business and Human Rights should continue in effect as soft law, be transformed into hard law, or operate in a mixed form.

Keywords: Soft Law, Hard Law, UN Guiding Principles on Business and Human Rights (UNGPs), COVID 19

\section{GiRiş}

Yumuşak hukuk sert hukukla ilişkisi doğrultusunda yasa benzeri, gönüllülük esasına dayalı, bağlayıcı olmayan belgeler olarak ifade edilirken ya bütünüyle dışlanmış, sert hukuku zedeleyen bir rakip olarak görülmüş ya da uluslararası hukukun duruk nitelikte olmadığını savunan görüşlerce savunulmuştur. Uluslararası hukukta güncelliğini koruyan yumuşak hukuk tartışmaları yumuşak hukukun sert hukuk yerine tercih edilebilirliği, ona karşıt konumda bulunması ve birbirlerini tamamlamaları üzerinde yoğunlaşmaktadır. Yumuşak hukukun varlığının artan oranda ve birçok örnekle gündeme gelmesi, varlık gösterdiği her bir alan ve konu kapsamında çözümlemeler yapılmasını gerekli kılmaktadır.

Bu çalışma öncelikli olarak yumuşak hukukun tanım ve kapsamı doğrultusunda farklılık ve benzerlik gösteren tartışmalara yer vermekte, uluslararası hukukta yürütülen yumuşak hukuk tartışmalarını sınıflamakta ve yumuşak hukuk ve sert hukuk ilişkisini irdelemektedir.

Uluslararası alanda İnsan Hakları ve İş Dünyası etkileşimin en önemli örneklerinden biri olan BM İş Dünyası ve İnsan Hakları Rehber İlkeleri (UNGPs) çalışmanın odak noktasını oluşturmaktadır. Bunun nedeni Rehber İlkeleri’nin önemli bir yumuşak hukuk örneği olarak ortaya çıkmış olmasıdır. Rehber İlkeler'e giden süreçöncelikle BM Küresel İlkeleri’nin (Global Compact) tanım ve kapsamının incelenmesiyle başlatılacak, tarihsel sıralamayla BM bünyesinde insan hakları ve iş dünyasına yönelik alınan kararlar incelenecektir. Belirtilen temellendirmenin ardından BM İş Dünyası ve İnsan Hakları Rehber İlkeleri bir başka başlıkla ele alınarak, COVID 19 krizinde ilkelerin etkinliği kapsamında güncel durum değerlendirilecektir. Çalışmanın son kısmında BM İş Dünyası ve İnsan 
Hakları Rehber İlkeleri, yumuşak hukuk çerçevesinde kalması gerektiğini ileri süren görüşler, sert hukuka dönüşmesini savunan görüşler ve ikisinin bir karışımıyla etkinliğini sürdürmesi gerektiğini savunan görüşlerle şekillenen yumuşak hukuk tartışmaları çerçevesinde değerlendirilecektir. $\mathrm{Bu}$ çözümlemeyle Türkçe literatürde yumuşak hukuka ilişkin tartışmaların görünürlügünün artmasına ve güncel tartışmaların uluslararası hukuk çerçevesinde değerlendirilmesine katkı sunmak hedeflenmektedir. Çalışma, yumuşak hukuk ve sert hukuk ilişkisinin BM İş Dünyası ve İnsan Hakları Rehber İlkeleri özelinde değerlendirilmesi ile sınırlı tutulmuştur.

\section{YUMUŞAK HUKUKUN TANIMI VE KAPSAMI}

Uluslararası hukukta yumuşak hukuk kavramının tanımlamaları konusunda tartışmalar sürse de çoğunlukla yasa görünümünde olan ancak bağlayıcı olmayan belgeler olarak tanımlanmakta, standartlar, üstlenmeler, bir politikaya ya da amaca yönelik bildiri ya da ortak bildiriler, Birleşmiş Milletler Genel Kurul ya da diğer çok taraflı organların kararları gibi ögelerle örneklenmektedir. Genel olarak uluslararası örgütler tarafından ya da en azından onlardan destek alınmasıyla oluşmaktadır. Çoğunlukla insan hakları, uluslararası ekonomik ilişkiler ya da çevrenin korunması konularıyla ilişkili konularda görülmektedir. ${ }^{1}$ Yumuşak hukuk farklı kaynaklardan var olan normları tek bir belgeyle birleştiren, bağlayıcı olmayan düzgüsel (normatif) çerçevenin bir örneğidir. ${ }^{2}$

Daha geniş bir ifadeyle uluslararası yumuşak hukuk normları, çok taraflı olarak bir uluslararası örgüt ya da bir organı (tavsiyeler) ya da devletler (siyasi düzenlemeler, hükümetler arası konferans kararları) tarafından oluşturulan, ilkeler ya da belirli kurallar olarak tanınmaktadır. Bununla birlikte devletler ve diğer aktörler tarafından ulusal ya da uluslararası hukukta gönüllülük temelinde uygulanan isteğe bağlı, bir yasanın gerektirmediği kurallardır. ${ }^{3}$

Tarihsel süreçte yumuşak hukukun geçmişi değerlendirilirken Ortaçağ hukuk sistemine ve özellikle uluslararası ticaret hukuku, özgün adılla lex mercatoria'ya gönderme yapılmaktadır. Bazıları tarafından ise 19.yy ve erken 20.yy sosyal hukuk ve yasal çoğulculuk kuramlarına dayandırılmaktadır. ${ }^{4}$ 1970’lerden beri, hukukun bağlayıcı doğasını bilgi kuramsal olarak farklı bir şekilde ifade etme olasılığını gündeme getirmesi ve sert hukuka yakın bir ulamda gösterilmesiyle uluslararası hukukçular arasında tartışılmaktadır. 1980'li yıllarda ve 1990’lı yılların başında tartışmalar sürerken yumuşak hukuku olumlu gören, yumuşak bir düzenlemenin hiç anlaşma olmamasından iyi olduğu görüşünü benimseyen çalışmalar çoğunluğu oluşturmuştur. 1990'ların bu konuda pekiştirme dönemi olduğu,

1 John P. Grant and J. Craig Barker, Encyclopaedic Dictionary of International Law (Oxford University Press 2009 ) 558.

2 Alexander Betts, 'Towards a 'soft law' Framework for the Protection of Vulnerable Migrants' (2008) 13 New Issues in Refugee Research (Policy Development and Evaluation Service, United Nations High Commissioner for Refugees) 162.

3 Gönderme ve uluslararası yumuşak hukuk-ulusal hukuk ilişkisi için bkz: Sergei Marochkin and Rustam Khalafyan, 'The Norms of International Soft Law in the Legal System of the Russian Federation' (2013) 6(2) Journal of Politics and Law 90, 91 .

4 Anna Di Robilant, 'Genealogies of Soft Law' (2006) 54(3) The American Journal of Comparative Law 499-554. 
sonrasında ise yumuşak hukukun kullanıldığı alanların ve tanımlamaların çeşitliliğinin artmasıyla tartışmalı yapısının sürdüğü görülmektedir. ${ }^{5}$

2. Dünya Savaşı sonrası dönemde, uluslararası hukukun kapsam ve aktör genişlemesinin bir sonucu olarak gelişen uluslararası kamu hukukundaki yapısal eksikliklerle birlikte uluslararası yumuşak hukukun etkinliği artmıştır. BM’nin kurulması, Soğuk Savaş’ın etkileri, anti kolonileşme süreci, bilim ve teknolojinin gelişmesi, uluslararası pazar ekonomisinin genişlemesi, devlet dışı aktörlerin rolünün artması gibi gelişmelerle yaşanan süreçte devletler dışında uluslararası örgütler, BM sistemi ve organları, uluslararası konferanslar, çok uluslu şirketler, hükümet dişı örgütler bugünkü uluslararası düzgüsel (normatif) düzeni şekillendirmektedir. ${ }^{6} \mathrm{Bu}$ uluslararası ortam yumuşak hukukun gelişmesine ve işlerlik kazanmasına zemin hazırlamıştır. Örneğin Uluslararası mülteci hukuku altındaki dayanışma ilkesi ve yük paylaşımının en iyi şekilde uluslararası yumuşak hukuk şemsiyesi altında anlaşılabileceği belirtilmekte, yumuşak hukukun uluslararası hukuk alanında bu gibi konularda tanınırlı̆̆ının gittikçe arttığına değinilmektedir. ${ }^{7}$ Özellikle uluslararası ticaret hukukunda yumuşak hukukun kazanımları sıkça tartışılmaktadır. ${ }^{8}$ Bu gelişmeler yumuşak hukukun birçok alanda sıklıkla gündeme geleceğini duyurmuştur.

\section{ULUSLARARASI HUKUKTA YUMUŞAK HUKUKA ILIŞKIN TARTIŞMALAR}

Yumuşak hukuk etkinliğini artırırken uluslararası alandaki varlığı tartışmalara neden olmuştur. Öncelikle yumuşak hukuk “eğer hukuksa neden yumuşak?” sorusunu gündeme getirmiştir. Yasal kuralları yasal olarak nitelemenin yolu bellidir ve kurallardan biri diğerinden daha yasal olarak nitelenmemektedir. Yasal söylem yumuşak hukukla birlikte yeni bir terimle tanışmıştır. ${ }^{9}$ Abbott ve Snidal’a göre yumuşak hukukun varlığı yasal düzenlemeler, yükümlülük, kesinlik ve yetkilendirme boyutlarından bir ya da daha fazlası zayıflatıldığında başlamaktadır. ${ }^{10}$ Yumuşak hukuk özellikle tutucu hukukçuların kabul etmekte zorlandıkları tarifi zor bir kavram olarak değerlendirilmekte, tanınmış kaynakların ölçütlerini karşılamayan bu kuralların uluslararası uygulamada artan oranda önemli rol oynadığı belirtilmekte ve söz konusu hukukçuların bu gerçekliğe gözlerini kapadığı yorumu yapilmaktadır. ${ }^{11}$

5 Jan Klabbers, 'Reflections on Soft International Law in a Privatized World' in Jan Klabbers (ed), Finnish Yearbook of International Law c. XVI (Leiden: Koninklijke Brill NV 2008) 314-316.

6 İlhami Alkan Olsson, 'Four Competing Approaches to International Soft Law' (2013) 58 Scandinavian Studies in Law $176,179$.

7 Agnès G. Hurwitz, 'The Collective Responsibility of States to Protect Refugees' (Oxford University Press 2009$) 163$.

8 Henry Deeb Gabriel, 'The Advantages of International Commercial Law: The Role of UNIDROIT, UNCITRAL and The Hague Conference’ (2009) 34(3) Brooklyn Journal of International Law 655, 672.

9 Laszlo Blutman, 'In the Trap of a Legal Metaphor: International Soft Law' (2010) 59 International and Comparative Law Quarterly 605, 609.

10 Kenneth W. Abbott and Snidal Duncan, 'Hard and Soft Law in International Governance' (2000) 54 International Organization 421, 422.

11 Hanspeth Neuhold, 'The Inadequacy of Law Making by International Treaties: Soft Law as an Alternative?' in Rüdiger Wolfrum and Volker Röben (eds) Developments of International Law in Treaty Making (Springer 2005) 47. 
Yumuşak hukukun var olmadığını savunan görüşe göre, yumuşak hukuk bağlayıcı hukuk ve hukuk olmayan ögeler arasında tanımlansa da uygulama açısından anlamlı bir orta ulam söz konusu değildir. ${ }^{12}$ Örneğin Shaw, yumuşak hukukun uluslararası yasal gelişme açısından dikkate değer bir konu olmakla birlikte hukuk olmadığını söylemiştir. Bunun yanında bir belgenin uluslararası politikada etki oluşturabilmesi için bağlayıcı bir antlaşma oluşturmasına gerek olmadığını da vurgulamıştır. Yumuşak hukuk olarak nitelendirilen belgelerin gerekli şartları sağladıklarında yasal olarak bağlayıcı kurallara dönüşebileceklerini ekleyerek yumuşak hukukun sunduklarının etkili ve önemli olduğunu ancak kendi kendilerine yasal kurallar oluşturmadıklarını belirtmiştir. ${ }^{13}$ Yumuşak hukukun uluslararası hukuktaki kesin yeri saptanamamış, belirsiz olmakla birlikte geleneksel uluslararası hukukçular yumuşak hukuku sert hukuk içindeki antlaşmalar ve yapılagelişten daha az hukuk olarak görmektedir. Bununla daha az yükümlülük getiren ve davranış üzerinde daha az etkili olan hukuk kastedilmektedir. ${ }^{14}$ Tartışmalar çoğunlukla hukuk olarak görülmemesi, hukuk olarak görülmese dahi etkinliğinin olumlu değerlendirilmesi ve yumuşak hukuk düzenlemelerinin herhangi bir kıyasa tabi olmadan daha fazla gündeme geleceğini savunan görüşler etrafında şekillenmiştir.

\section{A. YUMUŞAK HUKUK VE SERT HUKUK ILIŞKISi}

Yumuşak hukuk bağlayıcı değildir, kurallardan değil genel norm ya da ilkelerden oluşmaktadır, çok yönlüdür ve sert hukukla incelikli ve çok çeşitli ilişkileri bulunmaktadır. ${ }^{15}$ Yumuşak hukuk ve sert hukuk ilişkisinde, yumuşak hukukun iç hukuka ya da bağlayıcı uluslararası antlaşmalara güç kazandıracağı beklentisiyle oluşturulabildiği dolayısıyla bağlayıcı hukuku sırtladığı düşünülmektedir. Böyle bir tanımlamayla bağlayıcı olmayan anlaşmaların yalnızca teşvik edici ya da tamamıyla siyasi anlaşmalar olduğu görüşü dışlanmaktadır. ${ }^{16}$ Yumuşak hukuk metinlerinin sert hukukla aile benzerliği bulunduğu ancak yasal bir kaynaktan yoksun olmak gibi oldukça önemli bir noktada yetersiz kaldıkları belirtilmektedir. ${ }^{17}$ Yumuşak hukuku gereksiz bulan benzer bir görüşe göre hukukun geleneksel ikincil görüşü genellikle yumuşak hukuka gönderme yapılan işlevleri yerine getirmekte yeterlidir. ${ }^{18}$ Yumuşak hukukun kurallar ve ölçünler yelpazesi oldukça geniş olabilmektedir, sert hukuka benzer normlar içerebildiği gibi daha basit düzenlenmiş belgeleri de içerebilmektedir. Ayrıca belirsizlik ve farklılıkların yer aldığ durumlarla baş etmede sert hukukun başarısız olduğu bu gibi durumlarda uluslararası yumuşak hukukun daha etkili çözümler sunabileceği de görüşler arasındadır. ${ }^{19}$

12 Kal Raustiala, 'Form and Substance in International Agreements' (2005) 99(58) The American Journal of International Law 581, 586-588.

13 Malcolm N. Shaw, 'International Law' (Cambridge University Press 2008), 117-118.

14 Andrew T. Guzman, 'The Design of International Agreements' (2005) 16(4) The European Journal of International Law $583,584,591$.

15 A. E. Boyle, 'Some Reflections on the Relationship of Treaties and Soft Law' (1999) 48(4) International and Comparative Law Quarterly 901, 902, 913.

16 Timothy Meyer, 'Soft Law as Delegation' (2009) 32 Fordham Int'l L.J.888, 906, 907, 940.

17 Daniel Bodonsky, 'The Art and Craft of International Environmental Law' (Harvard University Press 2011 ), 14.

18 Jan. Klabbers, 'The Redundancy of Soft Law' (1996) 65(2) Nordisk Journal of International Law 167, 168.

19 Sebastian Paulo and Helmut Reisen, 'Eastern Donors and Western Soft Law: Towards a DAC Donor Peer Review of China and India?' (2010) 25(5) Development Policy Review 535, 543. 
Yumuşak ve sert hukuk birbirlerine seçenek oluşturabilmekte, tamamlayıcı ya da karşıt olabilmektedir. Tamamlayıcı olduklarında ilk olarak yumuşak hukukun zamanla gelişebileceği, sertleşebileceği ve sert hukuku oluşturabileceği, ikinci olarak ise sert hukukun yumuşak hukuk doğrultusunda genişletilebileceği ve geliştirilebileceği belirtilmektedir. Karşıt olduklarında ise yasal olarak yasalar çatışması söz konu olabilmektedir ya da siyasi açıdan devletler ve devlet dışı aktörler stratejik olarak sert hukuku baltalamak için de yumuşak hukuku kullanabilecektir. ${ }^{20}$ Örneğin Silahların Kontrolü konusunda antlaşmalara uyma meselesi tartışılırken yumuşak hukuk ve sert hukuk etkileşimi (tercih birleşimleri, karşıtlıkları vs.) sıklıkla gündeme gelmektedir. Silahların kontrolü alanında yumuşak hukuk sert hukuk yanında oldukça az yer bulsa da destekleyici rolü yadsınamamaktadır. ${ }^{21}$ Yumuşak ve Sert hukuku tamamlayıcı olarak görenler üç kampta ayrışmaktadır. Olgucu (pozitivist) yasal bilimciler yasal bağlayıcılıktan yoksun olmasından ötürü yumuşak hukuku sert hukuktan aşağıda görüp yine de sert hukukla sonuçlanabileceği için yabana atılmaması gerektiğini savunurken, inşacılığa yönelen bilim insanları devlet çıkarları algısının, anlayışların ve normların dönüştürülme sürecini kolaylaştırdığı için yumuşak ve sert hukukun tamamlayıcıllğını benimsemişlerdir. Kurumsalcı akılcı seçenek yaklaşımına göre ise devletler siyasi amaçlarına göre sert ya da yumuşak hukuku seçebilmektedir ve yumuşak hukuk sert hukukun maliyetlerinden ötürü başlangıçta elverişli olmaması nedeniyle tamamlayıcı özellik göstermektedir. ${ }^{22}$

Yumuşak ve sert hukukun birlikte kullanılıp kullanılamayacağı ya da birbirlerine seçenek oluşturup oluşturamayacağı tartışmaları Avrupa Birliği örneğinde sıkça gündeme gelmektedir. $A B$ çevre hukuku yumuşak hukukun sert hukukla birlikte kullanıldığı ve bu melezliğin oldukça iyi kotarıldığı alana en iyi örnek olarak sunulmaktadır. ${ }^{23}$ Bununla birlikte Avrupa Birliği istihdam politikasında yumuşak hukuku seçmiştir, bunun sebebi ise 1990 'ların ilk yarısında bu konuya ilişkin herhangi bir antlaşma yapılmamış olması olarak açıklanmıştır. Bazı durumlarda anlaşmalar bağlayıcı olmadığında karşı çıkan devletleri ikna etmek daha kolay olmaktadır. ${ }^{24}$ Belirli alanlarda yeni bağlayıcı normlar tartışmaya gerek duyulmadan, açık ve güvenilir bir rehberlik sağlayabilecek olması yumuşak hukuku değerli kılan özelliklerden biri olarak gösterilmektedir. ${ }^{25}$ Yumuşak hukuk denildiğginde akla gelen en önemli alanlardan biri olan uluslararası ticaret hukuku kapsamında Dünya Ticaret Örgütü (DTÖ) yumuşak hukukuna en çok gönderme yapan örgütlerden biridir. Yapısı ve işleyişinde yumuşak hukuku sert hukuka tamamlayıcı olarak ya da birbirlerine seçenek olarak sıklıkla kullanan örgüt yumuşak hukuk çerçevesindeki uygulamaları desteklemekte ve artırmayı amaçlamaktadır. ${ }^{26}$

20 Gregory C. Shaffer and Mark A. Pollack, 'Hard Versus Soft Law in International Security' (2011) 52(4) Boston Collage Law Review 1147, 1167.

21 Richard L. Williamson Jr., 'Hard Law, Soft Law, and Non-Law in Multilateral Arms Control: Some Compliance Hypotheses' (2003) 4(1) 59, 67-68.

22 Gregory C. Shaffer and Mark A. Pollack, 'Hard vs. Soft Law: Alternatives, Complements and Antogonists in International Governance' (2010) 9 (23) University of Minnesota Law School Legal Studies Research Paper Series 706, 722.

23 David M. Trubek and Louise G. Trubek, 'Hard and Soft Law in the Construction of Social Europe: the Role of the Open Method of Co-ordination' (2005) 11(3) European Law Journal 343, 362.

24 Armin Schäfer, 'Resolving Deadlock: Why International Organisations Introduce Soft Law' (2006) 12(2) European Law Journal 194, 207, 208.

25 Betts (n 3) 13.

26 Mitsuo Matsushita, 'A View on Future Roles of The WTO: Should There be More Soft Law in The WTO?' (2014) 17 
Bu doğrultuda yumuşak hukuk yalnızca ahlaki ve/veya siyasi yükümlülük doğurur anlayışının yanıltıcı olacağı çünkü yumuşak hukukun siyasi ve ahlaki olanlarla birlikte doğrudan ya da dolaylı yasal etkileri olabileceği belirtilmektedir. Yumuşak hukukun yapılageliş hukuku kuralı başlatabileceği ya da onun kanıtı olabileceği bu bağlamda oldukça önemli bir özelliği olarak sunulmaktadır. ${ }^{27}$ Yumuşak hukuk belirli olaylarla devlet uygulaması desteği olduğunda yapılageliş yaratan belgeler olarak nitelendirilebilmektedir. ${ }^{28}$

Yumuşak hukukun yumuşak hukuku benimseyen örgütler ilişkin bağlayıcı etkisi konuyla bağlantılı olarak önem taşımaktadır. Yumuşak hukuk, Genel Kurul örneğinde olduğu gibi örgütün üyelerini bağlamamakta ancak örgütü iç işlemlerinde aldığı karara uyumlu davranma konusunda bağlamaktadır. Bununla birlikte yumuşak hukuk var olan opinio juris’e ve devlet davranışlarına karşı bir normsa kendisi yasallık kazanarak daha önceki bir normun yasal statüsünü ya da bağlayıcı etkisini değiştirebilmektedir. Bir diğeri bununla bağlantılı olarak yapılageliş kuralı açısından manevi ögede kendisini göstermektedir. Yumuşak hukuk psikolojik etkiyi sağlamaya destek olabilmektedir. ${ }^{29}$ Yumuşak hukuk bütünüyle kapsamaya yeterli olmasa da davranış kuralları kapsamında değerlendirilmeye de uygun bir kavram olarak görülmektedir. Birçok davranış kuralı, özellikle uluslararası örgütler tarafından belirlenenler bu kapsamdadır. Zamanla bu davranış kurallarının da yumuşaktan serte dönüşebileceği bu bağlamda bunun hukukun belirginleşmesi için bir sıçrama tahtası olarak görülebileceği belirtilmektedir. ${ }^{30}$

Yumuşak hukuku uluslararası hukukun bütünüyle dışına iten yaklaşım, uluslararası hukukun devletler üzerindeki etkisinin azalacağı endişesi taşımaktadır. ${ }^{31}$ Olgucu yaklaşımlar, yumuşak hukuku sert hukuku yumuşattığı gerekçesiyle dişlayan ve kötüleyen bir tavır sergilemektedir. Bu yaklaşımın terkedilmesi gerektiğini savunanlar yumuşak hukukun, kuralların anlaşılması, biçimlendirilmesi ve yorumlanmasında fayda sağladığını belirtmektedir. Yumuşak hukuk uluslararası sistemin karmaşık doğasıyla uyumlu bir kavram olarak da görülmektedir. Buna göre yumuşak hukuk yadsınamaz biçimde yeni bir biçim olarak yasal sistemde yer bulmaktadır. ${ }^{32}$ Yumuşak hukuk tartışmalarına hız kazandıran örneklerin artışı bu savı desteklemektedir.

Journal of International Economic Law 701, 715.

27 Olsson (n 7) 193.

28 Dinah L. Shelton, 'Encyclopedia of Genocide and Crimes Against Humanity' (Thomson Gale, 2005) 567; Finn Seyersted, Common Law of International Organizations ( Nijhoff 2008) 220.

29 Tadensz Grnchalla-Wesierski, ‘A Framework for “Understanding Soft Law’ (1984) 30 McGill Law Journal 37, 52-57.

30 Helen Keller, 'Codes of Conduct and their Implementation: the Question of Legitimacy' in Rüdiger Wolfrum and Volker Röben (eds) Legitimacy in International Law (Max-Planck Institut, Springer 2008) 249, 295.

31 Matthias Goldmann, 'We Need to Cut Off theHead of the King: Past, Present, and Future Approaches to International Soft Law' (2012) 25(2) Leiden Journal of International Law 335, 344.

32 Ulrich Fastenrath, 'Relative Normativity in International Law' (1993) 4(1) European Journal of International Law 324, 339. 


\section{TARIHSEL SÜREÇTE BM IŞ DÜNYASI VE INSAN HAKLARI REHBER ILKELERi}

\section{A. BM KÜRESEL ILKELERI (UN GLOBAL COMPACT)}

BM Küresel İlkeleri (UN Global Compact) şirketlere insan hakları, çalışma standartları, çevre ve yolsuzlukla mücadele konularında evrensel ilkeler çerçevesinde hareket edilmesi üzerine çağrıda bulunan kurumsal sürdürülebilirlik girişimi olarak tanımlanmaktadır. Bu kapsamda hazırlanan 10 ilke şirketlere söz konusu alanlarda yol gösterici bir nitelik taşımaktadır. ${ }^{33}$ Küresel İlkeler’ in şirketlerin davranışları üzerinde denetleyici, değerlendirici ya da zorlayıcı bir araç olarak görülmemesi gerektiği vurgulanmakta ve bunun yerine şirketlerin yararı doğrultusunda ve ilkeler rehberliğinde şeffaflık ve hesap verebilirlik gibi ilkelerle hareket edilmesinin teşvik edildiği belirtilmektedir. BM bünyesinde çekirdeğini oluşturan İnsan Hakları Yüksek Komiserliği, Kalkınma Programı, Çevre Programı gibi yapılarla birlikte devletler, iş gücü, sivil toplum örgütleri gibi ilişkili tüm sosyal aktörlerle birlikte hareket eden bir ağ olarak görülmektedir. Küresel İlkeler’e dahil olunmasıyla sürdürülebilir ve kapsayııı bir küresel ekonominin parçası olunabileceği, küreselleşmeyle birlikte gelen sorunlara hızlı çözümler üretilmesinden ve risklerin değerlendirilmesinden yararlanılabileceği, geniş bir bilgi ağının paylaşllabileceği, deneyimlerin aktarılabileceği ve işbirlikleriyle teknik faydalar sağlanabileceği değerlendirilmektedir. ${ }^{34}$

Söz konusu ilkelerin uygulanmasına yönelik soru ve kaygılara yönelik adımlar da atılmıştır. Farklı ülke ve şirket örnekleriyle uygulamada karşılaşlabilecek zorluklara ilişkin kılavuzlar geliştirilmiştir. İnsan haklarına saygılı olmak konusunda tüm şirketlere sorumluluk yükleyen ve insan hakları politikaları yayımlamaya teşvik eden ilkeler hakkında detaylı tartışmalar yürütmek önemsenmiştir. Kılavuzda İlkeler'de yer alan kavramların şirketler için uygulamada ne anlam taşıdığı, şirketlerin bu süreçte kendilerine yöneltebilecekleri sorular, dikkat edilmesi gereken ve tartışmalı konulara değinilmiştir. ${ }^{35}$

İlkeler belirtilen konularda dört başlık altında sunulmuştur. İlk iki ilke insan haklarına ayrılmıştır. İlk ilkeye göre iş dünyası, ilan edilmiş insan haklarını desteklemeli ve haklara saygı duymalıdır. Bu kapsamda oluşabilecek olumsuz etkilerini de dikkate almalı ve önlemeli, etkilerini hafifletmeye çalışmalıdır. Zarar vermemenin ötesinde insan haklarını desteklemek için etkin bir biçimde eyleme geçilmelidir. Bu eylemler olumlu katkı sunmak adına atılan gönüllü eylemler olarak sınıflandırılmıştır. İnsan haklarını koruma, uygulama ve bu haklara saygı duyma devletlerin birincil sorumluluğundadır, diğer örgütlenmeler ve bireylerin bu konuda tamamlayıcı bir rolü bulunmaktadır. İş dünyası aktörlerinin bu konuda neler yapabileceği konusunda da yönlendirici olunmuştur. Öncelikle şirketler olumlu ve olumsuz biçimde insan haklarına yönelik olası etkilerinin farkında olmalıdır. Bununla birlikte temel alacakları belgeler, insan hakları evrensel beyannamesi,

33 United Nations Global Compact, 'What is the UN Global Compact' <https://www.unglobalcompact.org/what-isgc/mission> accessed 05 July 2021; Ayrıca bknz: UN Global Compact Network Türkiye, 'Hakkımızda', https://www. globalcompactturkiye.org/un-global-compact/ Erișim Tarihi: 05 Temmuz 2021.

34 UN Global Compact Office, 'The Global Compact Brochure' (United Nations 2004).

35 Shift, Oxfam and Global Compact Network Hollanda, 'İnsan Haklarına Saygılı İş Yapma: Şirketlere Yönelik Kılavuz’ (2016). 
Uluslararası Çalışma Örgütü (ILO) Çalışma Yaşamında Temel İlkeler ve Haklar Bildirgesi ve Human Rights Translated gibi uluslararası insan haklarını iş dünyası penceresinden inceleyen rehber ilkeler olarak sıralanmıştır. ${ }^{36}$ Nadir olasılıkla iç hukukun doğrudan uluslararası standartlarla çatışması durumunda aktörler uluslararası biçimde tanınmış insan hakları ilkelerine saygılı hareket etmenin yollarını aramalıdır. ${ }^{37}$ Şirketlerin insan haklarını koruma sorumluluğu devletlerin yükümlülüklerinden ayrı olarak değerlendirilmiştir, şirketler bu konuda zayıf ya da güçlü devletler içinde var olsalar da bu sorumluluklarını sürdürürler. ${ }^{38}$

Şirketler insan hakları etkileşiminin kapsamını, olası olumsuz etkilerini belirlerken üç etken üzerinden hareket etmelilerdir. Bunlardan ilki iş sahasının bulunduğu ülkeyi ve yerel şartları herhangi bir insan hakları konusunda karşılaşılabilecek zorluklar açısından değerlendirmektir. İkinci olarak şirketler uygulamalarının doğrudan dolaylı biçimde insan hakları ihlallerine yol açıp açmadığını ya da olumsuz bir etkisinin olup olmadığını değerlendirmelidir. Üçüncü olarak ise şirketlerin devletle, iş ortaklarıyla, üreticiler ve diğer devlet dışı aktörlerle olan ilişkileri bir insan hakları ihlaline neden olma olasılıkları üzerinden çözümlenmelidir. ${ }^{39}$

Şirketler insan haklarına saygı sorumluluklarını yerine getireceklerini bildiren belgeler üretmeli ve ilgili organlarınca bu belgeleri onaylamalılardır. Söz konusu belgeler bu sorumluluğun nasıl yerine getirileceğine ilişkin bir yol haritası sunmalıdır. Bu konuda şirketlere yardımcı olmak adına bir rehber de sunulmuştur. ${ }^{40}$ Şirketler alınabilecek önlemler konusunda da hazırlık yapmalı, etki değerlendirmesinden sonra eyleme geçtikten sonra da performansını izlemeli, raporlamalıdır. Yasal süreçlere dâhil olma konusunda da etkin rol oynamalıdır. Şirket içinde ve dışında insan haklarını teşvik edici eylemler üzerine düşünülmelidir. ${ }^{41}$

İkinci ilkeye göre iş dünyası, insan hakları ihlallerine suç ortaklığı yapmadığından emin olmalıdır. Bu suç ortaklığı, diğer işletmelerin, hükümet veya bireylerin yol açtığı insan hakları ihlallerine dâhil olmak olarak tanımlanmıştır. Bu suç ortaklığının genellikle iki ögeden oluştuğu belirtilmiştir. Birincisi şirket ya da şirketi temsil eden birinin eylem ya da eylemsizliği sonucu bir başkasını bu konuda yüreklendirme, meşrulaştırma gibi eylemler de dâhil olmak üzere bir insan hakkı ihlali

36 'Universal Declaration of Human Rights, General Assembly resolution 217 A (III) of 10 December 1948' (OHCHR) $<$ https://www.ohchr.org/Documents/Publications/FactSheet2Rev.1en.pdf> ; 'ILO Conventions and Recommendations' $(I L O)<$ http://www.ilo.org/global/standards/introduction-to-international-labour-standards/conventions-andrecommendations/lang — en/index.htm> accessed 10 July 2021; 'Human Rights Translated: A business Reference Guide' (Castan Centre for Human Rights Law, International Business Leaders Forum and Office of the United Nations High Commissioner for Human Rights 2008).

37 UN Global Compact, Annie Golden Bersagel, "Meeting the Responsibility to Respect in Situations of Conflicting Legal Requirements", A Good Practice Note endorsed by the United Nations Global Compact Human Rights Working Group on 13 June 2011.

38 UN Global Compact, "Guidance on Responsible Business in Conflict-Affected and High-Risk Areas: A Resource for Companies and Investors", UN Global Compact Office-PRI Publication, 2010.

39 ibid.

40 UN Global Compact and OCHR, 'A Guide for Business: How to Develop a Human Rights Policy', (United Nations Global Compact Office and Office of the United Nations High Commissioner for Human Rights, 2015)

41 'The Ten Principles of the UN Global Compact, Principle One: Human Rights' (UN Global Compact) < https://www. unglobalcompact.org/what-is-gc/mission/principles/principle-1> accessed 02 August 2021. 
gerçekleştirmesine yardımcı olmasıdır. İkincisi ise şirketin, eyleminin veya ihmalinin bu tür bir yardımı sağlayabileceğine dair bilgiye sahip olmasıdır. Suçlamalar, doğrudan, fayda sağlayan ve sessiz suç ortaklığı kapsamında gerçekleşebilecektir. ${ }^{42}$ Söz konusu ağ BM bünyesinde konunun etkin kılınması için önemli bir araçtır.

\section{B. BIRLEŞMIŞ MILLETLER'DE iş DÜNYASI VE INSAN HAKLARINA ILIŞKIN KARARLARIN INCELENMESi}

1999 yılında dönemin BM Genel Sekreteri Kofi Annan, Dünya Ekonomik Forumu çerçevesinde paylaşılan değerler ve ilkeleri değerlendirerek küresel ekonomiye yönelik küresel ilkeler oluşturmanın önemine vurgu yaparak ve daha önce yapılmış uluslararası düzenlemeler ve girişimlere göndermelerde bulunarak iş dünyası ve BM işbirliğinin düzenlenmesini gündeme getirmiştir. ${ }^{43}$ Tasarlanan ilkeler kabul eden katılımcıların uygulamalarını raporlamalarını da öngören bir metin oluşturularak bir Genel Kurul kararıyla 2000 yılında resmiyet kazanmıştır. Genel Sekreter ilkelerin uygulanmasını ileriye götürecek bu gelişmenin tüm katılımcılar tarafından memnuniyetle karşılandığını dile getirmiştir. ${ }^{44} \mathrm{BM}$ bünyesinde oldukça dikkate alınan ve geliştirilmesi üzerine birçok tartışma yürütülen söz konusu ilkeler için BM Global Compact Ofisi BM sistemiyle tüm katılımcıların etkileşimini geliştirmekte, özel sektör ve yerel ağların sürece katılımları ve birçok alanda işbirlikleri desteklenmektedir. ${ }^{45}$

BM'nin uluslararası alanda iş dünyasıyla etkileşiminin artmasını hedefleyen çalışmaları 2000'li yıllarda insan hakları çerçevesinde hız kazanmaya başlamıştır. 2002 yılında Sierra Leone'deki genel durumun değerlendirdiği bir Güvenlik Konseyi kararında, bölgedeki elmas üretim bölgeleri güvenlik ve çatışma kapsamında ele alınmıştır. Yasa dışı elmas ticaretinin bölgedeki çatışmaları tetiklediği belirtilmiş ve ilgili devletler, elmas endüstrisi ve özelde Dünya Elmas Konseyi anılarak bu yasa dışı ticaret ve silahlı çatışmaların bağının koparılmasındaki katkıları ve bu katkıların sürmesinin önemi dile getirilmiştir. ${ }^{46}$ Aynı örnek çerçevesinde alınan bir diğer kararda endüstri ve sivil toplumun elmasların belgelenmesi üzerine kurulan sisteme katkıları bir kez daha olumlu karşılanmıştır. Kimberley Süreci olarak tanımlanan sistemle bu bölgelerdeki elmasların yasal bir biçimde ticaretini sağlamak adına bir denetleme işleyişi oluşturulmuştur. Bu işleyişin sürdürülmesi çatışmaların ve

42 'The Ten Principles of the UN Global Compact, Principle Two: Human Rights' (UN Global Compact) <https://www. unglobalcompact.org/what-is-gc/mission/principles/principle-2> accessed 02 August 2021.

43 United Nations 'Secretary-General Proposes Global Compact on Human Rights, Labaour, Environment, in Address to World Economic Forum in Davos, Press Release' (1 February 1999) UN Doc SG/SM/6881 Başlangıçta dokuz ilke sayılırken 2004 tarihinde gerçekleşen Global Compact Zirvesi’nde Kofi Annan yolsuzlukla mücadeleye ilişkin 10.ilkenin ilkelere dâhil edildiğini duyurmuştur. United Nations 'Global Compact Summit Concludes with Emphasis on Need to Fight Corruption, Global Compact Leaders Summit Press Release' (24 June 2004) UN Doc ECO/70

44 United Nations 'Transcript of Press Conference by Secretary-General Kofi Annan at Headquarters' (26 July 2000 ) UN Doc SG/SM/7496

45 United Nations General Assembly 'Towards global partnerships: a principle-based approach to enhanced cooperation between the United Nations and all relevant partners' (7 February 2014) UN Doc A/RES/68/234 
dolayısıyla insan hakları ihlallerinin engellenmesi üzerinde etki taşımaktadır. ${ }^{47}$ Irak'taki insani yardım sürecinin değerlendirildiği kararlardan birinde ise tedarikçilerle sağlanacak iletişimin ve ulaşım sürecinin ihtiyaçların karşılanmasındaki önemine vurgu yapılmıştır. ${ }^{48}$

BM Ekonomik ve Sosyal Konsey, Ekonomik, Sosyal ve Kültürel Haklar başlığı altında ulus aşırı ticaret ortaklıkları ve diğer iş teşebbüslerinin insan hakları sorumlulukları üzerine bir takım normları paylaştı̆̆ı bir karar yayımlamıştır. Temel insan hakları normları ve belgelerinden hareketle söz konusu yapılar toplumun bir organı olarak insan haklarının güvence altına alınmasında sorumlu olarak nitelenmiştir. İnsan haklarına ilişkin tüm uluslararası düzenlemelere yer verilmekle birlikte Küresel İlkeler'e de göndermede bulunulmuştur. Artan iş ve ortaklık ağının ulusal sınırların ötesine taşındığı belirtilmiş, bu yapıların olumlu biçimde geliştirebilecekleri ögeler kadar insan haklarına ilişkin olumsuz eylemlere yol açma kapasiteleri de mevcut görülmüştür. İnsan haklarının evrenselliğine vurgu yapılarak düzenlenen normlar; genel yükümlülükler, eşit fırsat ve ayrımcılığa maruz kalmama hakkı, güvenlik hakkı, işçi hakları, ulusal egemenliğe saygı ve insan hakları, tüketicinin ve çevrenin korunmasına ilişkin yükümlülükler, uygulamanın genel hükümleri ve tanımlamalar başlıklarıyla sıralanmıştır. ${ }^{49}$

BM İnsan Hakları Yüksek Komiserliği, ulus aşırı ticaret ortaklıkları ve diğer iş teşebbüslerinin insan hakları sorumluluklarını ele aldığı kararı, 1995 yılında söz konusu ortaklık ve teşebbüslerin işleyişlerinin değerlendirilmesini öngören ve 1998’te bu temelden hareketle bir alt komisyon çalışma grubu oluşturulan kararlara göndermelerle başlamıştır. Kararda daha önce belirlenen normların uygulanmasına ilişkin önemli noktalara vurgu yapılmıştır. Bu doğrultuda çalışma grubunun tüm aktörlerle bilgi ve yorum alış verişinde bulunması normların uygulanmasına ilişkin soruların yanıtlanması ve sorunların giderilmesi önem taşımaktadır. BM yapılanması içerisinde bu sürece destek olabilecek işleyişlerin katkısı için de çağrıda bulunulmuştur. ${ }^{50}$ Belgelerde süregiden biçimde ulus aşırı ticaret ortaklıkları ve diğer iş teşebbüslerinin insan hakları sorumluluğuna vurgu yapan ifadeler kullanılmaktadır. ${ }^{51}$ Bununla birlikte ulusal yasal düzenlemelerin, devletlerin rolünün artırılmasının, yöntem ve materyaller geliştirilmesinin, insan hakları sorumluluğunu yerine getirmede katkı sunacağ değerlendirilmektedir. $^{52}$ İnsan haklarının ve temel özgürlüklerin korunmasında öncelikli sorumluluk ve yükümlülüğün devlete ait olduğu ifade edilerek söz konusu yapıların sorumluluğu da hemen ertesinde vurgulanmaktadır. İşlevsiz ulusal yasal düzenlemelerin küreselleşmenin olumsuz etkileriyle baş etmede yetersiz olacağı, bu olumsuz etkileri azaltamayacağı, ulusal, bölgesel ve uluslararası düzeyde var olan boşlukların giderilmesi gerektiği belirtilmektedir. Devletlerin ulus aşırı

47 UNSC Resolution 1459 (2003) (28 January 2003) UN Doc S/RES/1459

48 UNSC Resolution 1472 (2003) (28 March 2003) UN Doc S/RES/1472

49 United Nations Economic and Social Council 'Norms on the responsibilities of transnational corporations and other business enterprises with regard to human rights' (26 August 2003) UN Doc E/CN.4/Sub.2/2003/12/Rev.2

50 Office of the United Nations High Commissioner for Human Rights (OHCHR) 'Responsibilities of transnational corporations and other business enterprises with regard to human rights' (2003) UN Doc E/CN.4/Sub.2/RES/2003/16.

51 OHCHR 'Responsibilities of transnational corporations and related business enterprises with regard to human rights' (22 April 2004) UN Doc E/CN.4/DEC/2004/116

52 OHCHR 'Human rights and transnational corporations and other business enterprises-Human Rights Resolution' (20 April 2005) UN Doc E/CN.4/RES/2005/69 
ticaret ortaklıklarının ve diğer iş teşebbüslerinin yol açtığı ya da dâhil olduğu insan hakları ihlallerinin önüne geçilmesinde yükümlülüğü bulunduğu, ortaklaşa bir sorumluluğun var olması gerektiği ve etkin yasal başvuru yollarının önemi dile getirilmektedir. Bunlar çizilen çerçevenin "koru, saygı duy ve telafi et” olarak belirlenen üç sütununu oluşturmaktadır. Konuya ilişkin BM özel temsilciliğinin yetkisinin genişletilmesine karar verilerek temsilcilikten çalışmalarında cinsiyet temelli bir bakış açısı geliştirmesi, hassas gruplara mensup olan insanlara, özellikle çocuklara özel önem atfedilmesi, ilgili tüm kurum kuruluşlarla iş birliği halinde olması, İnsan Hakları Konseyi ve Genel Kurul'a yıllık raporlar sunması talep edilmiştir. ${ }^{53} \mathrm{Bu}$ tarihsel zemin, ilgili aktörleri yönlendirecek kapsamlı bir düzenleme arayışının bir sonucu olarak oluşmuştur.

\section{BM IŞ DÜNYASI VE INSAN HAKLARI REHBER ILKELERI (UNGPS)}

İnsan Hakları ve Ulus aşırı Ticaret Ortaklıkları ve diğer İş Teşebbüsleri Özel Temsilcisi John Ruggie 2005 ve 2011 yılları arasında gerçekleştirdiği çalışmalarla bir nihai rapor ortaya koymuştur. BM İş Dünyası ve İnsan Hakları Rehber İlkeleri (UNGPs) olarak başlıklandırılan rapor BM’nin "koru, saygı duy, telafi et" çerçevesinin uygulanması olarak detaylandırılmıştır. Raporda, insan hakları ve iş dünyası etkileşimine yönelik ilginin 1990'larda özel sektörün dramatik biçimde artış göstermesi ve ulus aşırı ekonomik faaliyetlerin hız kazanmasıyla bir sosyal farkındalıkla söz konusu olduğu böylelikle BM’nin gündemine de girdiği belirtilmiştir. BM bünyesindeki önceki girişimlerin daha genelleyici bir işlevi olduğu bununla birlikte devletlerin desteğinden yoksun biçimde iş dünyası ve insan hakları savunucuları arasında bir bölünmeye ve tartışmalara yol açtığı ifade edilerek bu konuda özel bir birim oluşturulmuş olması yeni bir sürecin başlangı1c1 olarak görülmüşsür. 2008'de belirtilen üç sütunun önemine tekrar vurgu yapılmış, bu tarihteki yetki genişlemesi ve çerçevenin uygulanabilir kılınması talebi doğrultusunda ilkelerin şekillendiği belirtilmiştir. İlkeler yalnızca uygulamalı bir rehberlik sağlamamakta var olan uygulamalarla iletişim halinde süreç odaklı bir rehberlik sunmaktadır. İlkelerin normatif katkısı yeni uluslararası hukuk yükümlülükleri getirmemekle birlikte var olan standart ve uygulamaların geliştirilmesinde önemli rol oynamaktadır. Alandaki geniş ağ düşünüldüğünde her bir aktöre uygulanacak bir çözüm aracı olarak görülmesi mümkün görünmemektedir bununla birlikte sağlanacak işbirliği önemli katkılar sunacaktır. İlkeler üç başlıkta ifade edilerek sonrasında detaylandırılmıştır. Bu başlıklar insan haklarının korunmasında devlet sorumluluğu, insan haklarına saygıda kurumsal sorumluluk ve yasal yollara erişimdir. ${ }^{54}$

Ertesinde konuya özel bir çalışma grubuyla birlikte bu grubun rehberliğinde İş Dünyası ve İnsan Hakları Forumu kurulmasına karar verilmiş, ilkelerin uygulamasının kolaylaştırılması, iyileştirilmesi ve sürdürülmesi hedeflenmiştir. ${ }^{55}$ Sonraki süreçte bu hedefler yerine getirilirken oluşabilecek

53 United Nations Human Rights Council (UNHRC), 'Mandate of the Special Representative of the Secretary General on the issue of human rights and transnational corporations and other business enterprises' (18 June 2008) UN Doc A/ $\mathrm{HRC} / \mathrm{RES} / 8 / 7$

54 UNHRC 'Report of the Special Representative of the Secretary General on the issue of human rights and transnational corporations and other business enterprises, John Ruggie, Guiding Principles on Business and Human Rights: Implementing the United Nations "Protect, Respect and Remedy" Framework' (21 March 2011) UN Doc A/HRC/17/31

55 UNHRC 'Human rights and transnational corporations and other business enterprises' (06 July 2011) UN Doc A/HRC/ RES/17/4 
aksaklıklar üzerine tartışılmış, ilkeler oluşturulurken BM sisteminin katkısının bir bütün olarak ele alınması olumlu karşılanmış, eşgüdüm halinde stratejik bir yaklaşıma duyulan ihtiyacın altı çizilmiş, Küresel İlkeler ağının bu ilkelerin uygulanmasında önemli katkıları olacağı değerlendirilmiştir. ${ }^{56}$ Rehber İlkeler'e kaynaklık eden Ruggie sürecinin paydaşları plana dâhil eden yapısı BM’deki ilişkili girişimlerle desteklenmiş ve BM gündeminde de önemli yer bulmuştur. Özellikle forum paydaşlara, hükümetlere, iş dünyası ve sivil topluma yıllık gözden geçirme olanağı sunmuştur. Bilgi paylaşımın artması da forumu öne çıkarak özelliklerdendir.

Konu kapsamında ulus aşırı ticaret ortaklıkları ve diğer iş teşebbüslerinin faaliyetlerini uluslararası insan hakları hukuku çerçevesinde düzenleyen, uluslararası ve yasal bağlayıcılı̆̆ı olan bir belge oluşturulabilmesi için hükümetler arası açı uçlu bir çalışma grubu kurulmasına karar verilmiştir. Yürütülecek tartışmalardan çıkan sonuçlarla, devletler ve ilgililerden toplanacak çıktılarla metnin olası ilkeleri, kapsamı ve ögelerinin belirlenmesi hedeflenmiştir. ${ }^{57}$ Bir uluslararası antlaşma hedefini gözeten görüşler yumuşak hukuk tartışmalarının da önemli bir parçasını oluşturmaktadır.

Sivil toplumun ve hükümet dışı örgütlerin iş dünyasıyla bağlantılı insan hakları ihlalleri konusunda farkındalıkoluşturulmasınakatkısunacağı değerlendirilmekteilkelerin etkinbiçimdeuygulanmasında ulusal eylem planlarının oluşturulması teşvik edilmektedir. Mağdurların yasal yollara ulaşmasındaki engellerin giderilmesi için işbirliği halinde olunması gerekliliği vurgulanmıştır. ${ }^{58}$ Hesap verebilirlik ve kanun yoluna erişim başlığıyla düzenlenen bir diğer kararda, tüm iş teşebbüslerine Küresel İlkelerde ve diğer uygulanabilir standartlarda da belirtilen insan haklarına saygı sorumluluklarını yerine getirme çağrısında bulunulmuştur. $\mathrm{Bu}$ standartlar hukukun üstünlüğüne saygıyı teşvik eden girişimlere etkin biçimde katkı sunma, yerel yasal süreçlerdeki iyi niyetin bir parçası olma ve şikâyetlere hızlı çözümler üretebilmek için etkin işleyişler geliştirme olarak örneklenmiştir. ${ }^{59}$

Çalışma Grubunun görevlerini etkin bir biçimde yerine getirmesi için bölgesel ve uluslararası düzeyde tüm ilgili kuruluşlarla işbirliğinin önemine ve BM’nin tüm ilgili organlarıyla grubu desteklemesine vurgu yapılmıştır. ${ }^{60}$ Devletlere de $\mathrm{BM}$ bünyesindeki tavsiyeleri göz önünde bulundurarak devlet temelli yargısal ya da yargısal olmayan işleyişlerin iyileştirilmesi konusunda ve iş dünyasının insan hakları ihlallerine karıştığı örneklerde hesap verebilirlik ve mağdurların yasal yollara erişiminin artırılması için ilgili hükümetler arası süreçlerle çalışma konusunda çağrıda bulunulmuştur. ${ }^{61}$

56 UNHRC 'Contribution of the United Nations system as a whole to the advancement of the business and human rights agenda and the dissemination and implementation of the Guiding Principles on Business and Human Rights' (16 October 2012) UN Doc A/HRC/RES/21/5

57 UNHRC 'Elaboration of an international legally binding instrument on transnational corporations and other business enterprises with respect to human rights' (14 July 2014) UN Doc A/HRC/RES/26/9

58 UNHRC 'Human rights and transnational corporations and other business enterprises' (15 July 2014) UN Doc A/HRC/ $\mathrm{RES} / 26 / 22$

59 UNHRC 'Business and human rights: improving accountability and access to remedy' (15 July 2016) UN Doc A/HRC/ $\mathrm{RES} / 32 / 10$

60 UNHRC 'Business and human rights: mandate of the Working Group on the issue of human rights and transnational corporations and other business enterprises' (14 July 2017) UN Doc A/HRC/RES/35/7

61 UNHRC 'Business and human rights: improving accountability and access to remedy' (18 July 2018) UN Doc A/HRC/ $\mathrm{RES} / 38 / 13$ 


\section{COVID 19 KRIZINDE BM IŞ DÜNYASI VE INSAN HAKLARI REHBER ILKELERI'NIN ETKINLIĞi}

Küresel İlkeler’in COVID 19 salgını gibi küresel krizler kapsamındaki ilişkisi ve devletlerin kriz ve iyileşme dönemi süresince sorumlu iş politikalarına olan ihtiyacı tanınarak, BM İş Dünyası ve Rehber İlkelerỉnin, bugüne dek verilen tavsiyelerin ve çalışma grubu gibi işleyişlerin bu süreçte de etkin biçimde uygulanmaya devam etmesi gerekliliği vurgulanmıştır. ${ }^{62}$ COVID 19 bugüne dek iş hayatı ve insan hakları etkileşiminde atılmış adımları ve geliştirilen ilkeleri dönüşüme uğratmıştır. Bu durumun bir kriz yaratması kabullenilmekle birlikte bir fırsata dönüştürülebileceği de vurgulanmaktadır. İnsan haklarını odak noktasına alan yaklaşımlarla iş dünyasının var olan düzenlemeleri, boşlukları ve yetersizlikleri yeniden gözden geçirerek işbirlikleri geliştirmeleri önerilmektedir. ${ }^{63}$

COVID 19'a devletler ve iş dünyası tarafından verilecek karşılığın mevcut insan hakları standartları çerçevesinde verilmesi önem taşımaktadır. Bu doğrultuda BM Rehber İlkeleri’ne uyum gösterilmesinin önemi gündeme gelmiştir. Salgının öngörülemeyen yanlarıyla birlikte, sürecin devam ediyor oluşu ve birçok farklı şekilde krizlere neden oluyor olması verilen karşılıkları da karmaşıklaştırmaktadır. Bu doğrultuda BM İş Dünyası ve İnsan Hakları Rehber İlkelerinin daha önce "insan haklarının korunmasında devlet sorumluluğu, insan haklarına saygıda kurumsal sorumluluk ve yasal yollara erişim” olarak belirtilen üç sütunu kapsamında ve "koru, saygı duy ve telafi et" çerçevesinde bu önemli kriz için bazı önerilerde bulunulmuştur.

İnsan haklarının korunmasında devlet sorumluluğunu içeren ilk sütunda devletler COVID 19'un ekonomik etkisini hafifletmek için alınan önlemler doğrultusunda, özellikle en güvencesiz ve savunmasız durumlarda çalışanların korunmasını odak noktası olarak belirlemelidir. Devletler bu kriz yönetilirken ticari kuruluşların insan haklarına saygı duymasını zorunlu hale getirmek ve uygulatmak adına yasal ve siyasi önlemlerin akılcı bir karışımını yürütmelidir. İkinci sütunda yer alan insan haklarına saygıda kurumsal sorumluluk başlığıyla kriz süreci ilişkilendirildiğinde, devletlerin insan haklarına saygı yükümlülüklerini yerine getirmelerinin yanında tüm şirketlerin ekonomik zorluklar ve toplum sağlığı krizleri süresince bu konuda sorumlu olduğu vurgulanmıştır. Yasal yollara erişim olarak ifade edilen üçüncü sütunda ise COVID 19 sürecinin başından beri haksız işten çıkarma, uygun olmayan koşullarda çalıştırılma gibi konular gündeme gelmektedir. $\mathrm{Bu}$ gibi durumlarda uluslararası insan hakları hukuku ve Rehber İlkeler oldukça açıktır, bu ihlallerden etkilenenler mutlaka etkin bir yasal sürece erişmelidir. Kriz zamanlarında bu sütun daha fazla önem taşımaktadır. Uygun şikâyet mekanizmaları işletilmelidir. Söz konusu mekanizmalar çevrim içi seçeneklere imkân tanıyacak biçimde düzenlenmeli, salgın süresince ortaya çıkabilecek durumları da kapsamına almalıdır. ${ }^{64}$

62 UNHRC 'Business and human rights: the Working Group on the issue of human rights and transnational corporations and other business enterprises, and improving accountability and access to remedy' (23 July 2020) UN Doc A/HRC/ RES/44/15

63 International Organisation of Employers (IOE), '\#UNGPsPlus10, Achievements, challenges, and the way forward in the uptake and implementation of the UN Guiding Principles on Business and Human Rights' (European Union February 2021).

64 OHCHR 'Human Rights at the Heart of Response, Business and Human Rights in times of COVID-19' (October 2020) 
10 ilkenin benimsenmesi COVID 19'un yol açtığı zorlu koşulların, hasarların ve değişimin sonuçlarının iyileştirilmesi için oldukça temel bir kaynak olarak görülmekte ve sıklıkla dile getirilmektedir. İş dünyasının bu süreçteki dönüştürücü rolü vurgulanmakta Küresel İlkeler ağının bu doğrultuda önemli bir bağlantı oluşturduğuna dikkat çekilmektedir. ${ }^{65}$ Bu kapsamda Küresel İlkeler, BM COVID 19 Response'un bir parçası olarak \#UnitingBusiness rehberlik ve destek ağını geliştirmiştir. İş dünyası liderlerine COVID 19 salgınından etkilenen çalışanları, toplulukları ve şirketleri desteklemek ve şirketlere rehberlik ve destek sağlamak için çağrıda bulunulmuştur. COVID 19’un sürdürülebilirlik üzerindeki etkilerini çözümlemek adına, cinsiyet eşitliği, iklim, temiz iş, sürdürülebilir finans, insan hakları, okyanus, yolsuzlukla mücadele, su yönetimi başlıkları belirlenmiş ve şirketlere bu başlıklar altında kolaylaştırıcı yönergelerle birlikte bilgilendirici görsel kaynaklar sunulmuştur. ${ }^{66}$ Krize karşı yürütülen bu işleyişs sırasında Rehber İlkeleri'nin uygulanması, var olan haliyle etkinliğini sürdürmesi ve bağlayıcı bir metinle varlık göstermesi konusundaki tartışmaları güçlendirmiştir.

\section{YUMUŞAK HUKUK TARTIŞMALARI ÇERÇEVESINDE BM IŞ DÜNYASI VE INSAN HAKLARI REHBER ILKELERININ DEĞERLENDIRILMESi}

Ulus aşırı ticari ortaklıklar için bağlayıcı metinler üretme girişimi 1970’lere dayanmaktadır. Bu ilk girişimlerde insan hakları konusu yer bulmamıştır. Yumuşak hukuk yaklaşımlarının devreye girişiyle girişimler hız kazanmış önceki bölümlerde çerçevesi çizilen Küresel İlkeler ile birlikte iş dünyası ve insan hakları etkileşimi önemli bir noktaya ulaşmıştır. Ruggie’nin Komisyon’a sunduğu rapor ve bunun neticesinde ortaya çıkan Rehber İlkeler tartışmaların odağını oluşturmaktadır. Ruggie insan haklarının korunması konusunda mevcut boşluklara işaret ederken iyileştirmenin uluslararası hukuk çerçevesinde olabileceğine de değinmektedir. Devletler ve şirketler arasındaki ayrışma, şirketlerin uluslararası hukuk düzenlemelerine tabi olmasını gerekli kılar gibi görünse de yasal yaptırım ve siyasi uygunluk konusundaki sorular yanıtlanamamaktadır. Bireysel yükümlülük anlayışı da süreci zorlaştırmaktadır. Küresel yönetişimdeki dengesizlikler tüm aktörleri kapsayan daha geniş bir bakış açısıyla ele alınmalıdır. Bu tartışma yasal alanın ötesine taşmaktadır ancak ondan bağımsız ele alınmayacaktır. ${ }^{67}$ Insan hakları ve iş dünyasının birbirinden farklı olarak gelişen alanlar olması ve bir arada anıldıkları oldukça az kesişim noktasına sahip olmaları birbirlerine uyum sürecini zorlaştıran ögeler olarak görülmektedir. BM Küresel İlkeleri'yle birlikte gelişen algıla birlikte her ne kadar zorlayıcılık işleyişinden yoksunluk gibi önemli zorluklarla karşılaşılsa da iki alanın yadsınamaz bir uyumlaştırma gelişimi gösterdiği görüşler arasındadır. ${ }^{68}$

UN Doc https://www.ohchr.org/Documents/Issues/Business/BusinessAndHR-COVID19.pdf accessed 25 August 2021.

UN Global Compact, 'UN Global Compact Strategy 2021-2023' (19 January 2021) <https://ungc-communicationsassets.s3.amazonaws.com/docs/about_the_gc/UN-GLOBAL-COMPACT-STRATEGY-2021-2023.pdf> accessed 20 August 2021.

66 UN Global Compact, '\#UnitingBusiness to Respond to COVID 19’<https://www.unglobalcompact.org/take-action/20thanniversary-campaign/uniting-business-to-tackle-covid-19> accessed 21 August 2021.

67 John Gerard Ruggie, 'Business and Human Rights: The Evolving International Agenda' (2007) 101(4) The American Journal of International Law 819, 838-840.

68 Michael K. Addo, 'Is Business and Human Rights Suitable for the Compliance Function?' (7 January 2020) The University of Chicago Law Review Online <https://lawreviewblog.uchicago.edu/2020/01/07/is-business-and-human- 
Yumuşak ve sert hukuk tartışmaları kapsamında görüşler, İlkeler'in yumuşak hukuk çerçevesinde kaldığı sürece yerinde sayacağı ya da oldukça küçük adımlar atılabileceğini, ancak bir antlaşmayla söz konusu hedeflere ulaşllabileceğini savunanlar ve ilkelerin olumlu etkisine vurgu yaparak, bir antlaşmanın görüşmelerinin dahi yıllarca sürebileceğini ve çoğunluk sağlanamayabileceğini ve hedeflenen odaklardan uzaklaşılabileceğini savunanlar arasında bölünmektedir. ${ }^{69}$ Küresel İlkeler gibi gönüllü girişimlerin bağlayıcllıktan yoksun oluşunun birçok açıdan telafi edebileceğini öngören görüş, girişimin bir havuç-sopa yöntemine sahip olmasını örneklemiştir. Havuç gönüllülük ve taraflar için esnekliği temsil ederken sopa, uyum göstermeyen şirketlerin itibarını zedeleyen yaptırımları içermektedir. Sürecin yumuşak hukukla başlatılması kimseyi dışlamayan geniş oranda bir katılımın söz konusu olmasını sağlamaktadır, bu görüşe göre şirketler yolun başında sert hukuk içeren bir bağlayıcilık istememektedir. ${ }^{70}$ Yumuşak hukuk düzenlemeleriyle yakalanan canlılığın sert hukuka dönüşüm söz konusu olduğunda kaybedilebileceğini öngören görüşler de bulunmaktadır. Farklı paydaş gruplarının yasal sınırlar, temel kavramların tanımlanması, kesinlik ve esneklik dengesi gibi konularda farklı görüşlere sahip olmasının bu dönüşümü zorlaştıracağı düşünülmektedir. ${ }^{71}$

Rehber İlkeler'in yasal boşluklarını doldurma girişimi, ilkelerin yumuşak hukuk niteliğine ilişkin şüpheler ve ilerleme kaydedilmediğine yönelik görüşlerle birleşerek bağlayıcı bir uluslararası antlaşma savunuculuğuna dönüşen bir hareket başlatmıştır. Bu hareket sınırları belli olan, öz ve uygulanabilir bir düzenlemeye olan ihtiyacı vurgulamaktadır. ${ }^{72}$ Yasal kesinliğin olması gerektiğini savunan görüşe göre yumuşak hukuk uygulamalarının artışı şirketlere güçlü haklar sağlayan, insan hakları yükümlülükleri getirmeyen ve de facto insan hakları ihlallerine yol açan bir yasal asimetriyle sonuçlanmaktadır. ${ }^{73}$ Konuya ilişkin yapılacak bir antlaşmanın, ilgili aktörlerin uluslararası sistemdeki yerini, insan hakları sorumluluklarını, birbirleriyle olan ilişkilerini belirginleştirerek, devlet temelli hukuk ve kurumsal davranış kuralları arasında da birleştirici bir görev üstlenebileceği de düşünülmektedir. ${ }^{74}$

rights-suitable-for-the-compliance-function-by-michael-k-addo/ > accessed 10 August 2021.

69 Doug Cassel, 'Does the World Need a Treaty on Business and Human Rights? Weighing the Pros and Cons' (Notre Dame Law School Notre Dame London Centre 14 May 2014). Konferans oturumunun tamamı Business and Human Rights Resource Centre youtube adresinde mevcuttur. $<$ https://www.youtube.com/watch?v=0AIq9dtbkXI $>$ accessed 01 September 2021.

70 Roya Ghafele and Angus Mercer, 'Not Starting in Sixth Gear': An Assesment of the UN Global Compact's Use of Soft Law as a Global Governance Structure for Corporate Social Responsibility' (2011) 17(1) U.C. Davis J. Int'l L. \& Poly 41, 49-53; 59-60. Yazarlar girişim ve yumuşak hukuk ilişkisinin durumunu bir dağ bisikletçisine benzetmişlerdir. Yasallık izgesinde yumuşak hukuk ilk vitese, sert hukuk ise altıncı vitese karşlık gelmektedir. Yolculuk altıncı viteste başlayamayacaktır. Dağ bisikletçisinin yolculuğunda olduğu gibi birinci viteste, yumuşak hukukla başlayarak bu alanda gelişim gösterilebilecektir.

71 Kumaravadivel Guruparan and Jennifer Zerk, 'Influence of soft law grows in International governance' (Chatham House, The Royal Institute of International Affairs, 17 June 2021) <https://www.chathamhouse.org/2021/06/influence-soft-lawgrows-international-governance> accessed 02 September 2021.

72 European Parliament, Directorate-General for External Policies, Policy Department, 'Implementation

of the UN Guiding Principles on Business and Human Rights' (February 2017) EP Doc EP/EXPO/B/COMMITTEE/ FWC/2013-08/Lot8/09, doi:10.2861/29813

73 Julia Bialek, 'Evaluating the Zero Draft on a UN Treaty on Business and Human Rights: What Does it Regulate and how Likely is its Adoption by States?' (2019) (9) Goettingen Journal of International Law 501, 504-505.

74 Larry Cat'a Backer, 'Moving Forward the UN Guiding Principles for Business and Human Rights: Between Enterprise 
Antlaşmanın, devletlerin insan haklarını koruma sorumluluğunu mevcut çerçevede açıklığa kavuşturması ve güçlendirmesi, antlaşma doğrultusunda devletlerin ulusal eylem planlarıyla raporlama yapmasının sağlanması, iş ortaklıklarına yönelik insan hakları yükümlülüklerini zorunlu kılması ve süreci takip etmesi ve mağdurların yasal destek almasını garanti altına almak için işleyişler geliştirmesini şart koşan görüşler de mevcuttur. Bu konudaki herhangi bir yasal bağlayıcı metin bu ögelerin her birini içermelidir. ${ }^{75}$ Ruggie, küresel sorunların küresel antlaşmalarla çözülmesi gerekliliğine olan yaygın kanının karmaşık ve tartışmalı konular için geçerli ve uygun olmadığını ifade etmektedir. İlkeler kural koyucu olarak değil insan haklarını desteklemek için bir sosyal alt yapı oluşturmak amacıyla geliştirilmiştir. Bununla birlikte ilkelerin koyduğu hedefler iç hukuklarda sert hukuk olarak düzenlenerek ileri taşınmaktadır. Bu gelişmeler bölgesel ve ulusal düzeyde sorunların tartışılmasına ve çözülmesine olanak tanıyacaktır. Ruggie’ye göre bu konuda yapılacak bir uluslararası antlaşmanın başarılı olması pek mümkün görünmemektedir. ${ }^{76}$

Uluslararası bir antlaşmanın önündeki engellerden biri şirketlere atfedilecek insan hakları yükümlülüklerinin kapsamı konusunda uzlaşıya varılmasının oldukça zor olması olarak görülmektedir. Bu görüşe göre, ilkelerde devletlerin insan haklarını koruma görevi ve iş dünyasının insan haklarına saygı göstermesi arasında yapılan belirgin ayrım farklı devlet yapılarıyla - örneğin uygun önlemleri alamayan bir ülkede bulunan bir şirketin bu boşlukları doldurup doldurmayacağı gibi sorularla - çeşitlilik gösterecektir. ${ }^{77}$ İş Dünyası ve insan hakları konusundaki düzenlemeler tartışılırken tanımlamalar ve yasallık başlıca sorunlar olarak belirlenmektedir. İnsan hakları konusundaki kurumsal sorumluluğunun kapsamının ne olduğu ve nasıl uygulanacağı ile bu alanda yeterli bir yasal yönetişim biçiminin onaylanabilmesinin nasıl mümkün olacağı temel sorular olarak sunulmaktadır. Yasallıkla ilgili soru işaretinin Ruggie’nin çalışmalarında da görüldüğü ileri sürülmüştür. Konuya ilişkin bir uluslararası antlaşma konusunda uzlaşı olmadığı ve buna ihtiyaç duyulduğu belirtilirken sivil toplum örgütlerinin antlaşma yapılması yönündeki baskısının etkili olabileceği de eklenmektedir. ${ }^{78}$

Yumuşak hukuk ve sert hukuk ilişkisinin ele alındığg bölümden hareketle bir çözümleme yapıldığında Rehber İlkeler’e yönelik tartışmaların da yumuşak ve sert hukukun seçenek olarak görülmesi, tamamlayıcılığg ve karşıtlığı üzerinden yürütüldüğü görülmektedir. Söz konusu tamamlayıcılık daha çok bir kaynaştırma, birlikte kullanma şeklinde ifade edilmektedir.

Social Norm, State Domestic Legal Orders, and the Treaty Law That Might Bind Them All' (2015) 38(2) Fordham International Law Journal 457, 547, 541.

75 Oliver de Schutter, 'Towards a New Treaty on Business and Human Rights' (2015) 1 Business and Human Rights Journal $41,43$.

76 John G. Ruggie, 'Social Norms, Soft Law, Hard Law: The Evolution of Business and Human Rights', (The Castan Centre for Human Rights Law, Monash Business School and Global Compact Network Australia, Public Lecture, Docklands, 30 April 2019) <https://www.monash.edu/law/research/centres/castancentre/public-events/events/2019/socialnorms,-soft-law,-hard-law-the-evolution-of-business-and-human-rights> accessed 02 September 2021. Konuşmanın tamamı "The Castan Centre for Human Rights Law" youtube hesabinda yer almaktadır <https://www.youtube.com/ watch? $\mathrm{v}=\mathrm{VbAt2VjtBF} 4>$ accessed 02 September 2021.

77 Ramona Elisabeta Cirlig, 'Business and human rights: from soft law to hard law?' (2016) 6(2) 228, 243-244.

78 Brigitte Hamm, 'The Struggle for Legitimacy in Business and Human Rights Regulation-a Consideration of the Processes Leading to the UN Guiding Principles and an International Treaty' (2021) Human Rights Review. 
Yumuşak hukuk ve sert hukukun birbirlerine seçenek oluşturmak zorunda olmadıklarını savunan görüşler, amaç iş dünyasında insan haklarının korunması olduğunda bağlayıcı yükümlülüklerin şirketler tarafından kazançlı olmayacağını, bu iki alanı birleştiren girişimlerin temelde yumuşak hukuk doğasına sahip olsalar da sert hukuk ögeleriyle birlikte hareket ettiklerinde norm oluşturmakta etkili olabileceğini ileri sürmektedir. Dolayısıyla yumuşak hukuk sertleşmeden, etkili dengeli bir sert hukuk karışımıla uygulamada başarılı olabilecektir. ${ }^{79}$ Şirketlerin daha katı bir düzenlemeden kaçınmak için yumuşak hukuku tercih ettikleri savına karşılık bazı yazarlar da bunun tam tersi biçimde yumuşak hukuk girişimlerinin zorlayıcı düzenlemeleri nedeniyle tercih edildiklerini ileri sürmüşlerdir. ${ }^{80}$ Aynı zamanda Rehber İlkeler, sert hukuk gerekliliklerine uyum göstermek için yol gösterici bir araç olarak görülebilmektedir. Şirketler bu ilkeleri bir rehber olarak görüp riskleri ve önlemleri belirleyerek daha şeffaf düzenlemeler oluşturabileceklerdir. ${ }^{81}$

İş dünyası ve insan hakları alanlarında yumuşak hukuk ve sert hukuk tercihlerinin alandaki birçok aktör arasında da farklılık gösterebileceği tartışılması gereken bir diğer konu olarak ortaya çımaktadır. Bu seçimlerin getirilerinin her zaman belirleyici olmayabileceği, bazı iş dünyası aktörlerinin rakiplerini göz önünde tutarak sert hukuk yaklaşımlarını benimseyebileceği, hükümet dışı örgütler ve bağlı iş kollarının yumuşak hukuku sert hukuka başlangıç olarak tercih edebileceği örneklenerek her aktör ve durum özelinde tercihlerde değişkenlik gösterebileceği çözümlemeler arasındadır. ${ }^{82}$ Bununla birlikte bir antlaşma söz konusu olduğunda hangi insan haklarını ve şirketleri kapsayacağı, ev sahibi devletlerin, diğer devletlerdeki şirketlerinin eylemlerinden sorumlu tutulup tutulamayacağı, yaptırım ögelerinin neler olacağı gibi sorular belirsizliğini korumaktadır. ${ }^{83}$

Ruggie ve Sherman, FIFA (Fédération Internationale de Football Association)'nın Rehber İlkeleri tanıyarak sözleşmeli ve tedarik zincirindeki ortakları için zorunlu tutacağına ilişkin duyuruyu örnekleyerek ilkelerin özel hukuk sözleşmeleri için bir insan hakları vurgusu getirdiğini belirtmiş, yeni lex mercatoria olarak ifade ederek, bu etkinin farklı alanlarda da sürebileceğini ileri sürmüşlerdir. $\mathrm{Bu}$ durumun sert hukuk ve yumuşak hukuk karışımı alanlarda sürece aşina olmayan uygulayıcılar tarafından zorlayıcı olabileceğini ve henüz yolun başında olunduğunu ifade etseler de giderilmesi gereken boşluklar konusunda da olumlu görüş bildirmişlerdir. ${ }^{84}$ Devlet kontrolünün ötesine taşan

79 Barnali Choudhury, 'Balancing Soft and Hard Law for Business and Human Rights' (2018) 67(4) International and Comparative Law Quarterly 961, 986.

80 Onna van den Broek, 'Soft Law Engagements and Hard Law Preferences: Comparing EU Lobbying Positions between UN Global Compact Signatory Firms and Other Interest Group Types' (2021) 23 Business and Politics 383, 405. Yazar gözlemleriyle desteklediği görüşünü David Vogel, 'Private global business regulation' (2008) 11 Annual Review of Political Science 261-82 künyeli çalışmaya atfen bir alternatif gerçeklik olarak ifade etmiştir.

81 Rae Lindsay, Anna Kirkpatrick and Jo En Low, 'Hardly Soft Law: The Modern Slavery Act 2015 and the Trend Towards Mandatory Reporting on Human Rights’ (2017) 18(1) Business Law International 29, 50.

82 Kishanthi Parella, 'Hard and Soft Law Preferences in Business and Human Rights' (2020) 114 AJIL Unbound 168, 173.

83 Cassel, 'Does the World Need a Treaty on Business and Human Rights? Weighing the Pros and Cons' (n 75).

84 John Gerard Ruggie and John F. Sherman, 'Adding Human Rights Punch to the New Lex Mercatoria : The Impact of the UN Guiding Principles on Business and Human Rights on Commercial Legal Practice' (2015) 6(3) Journal of International Dispute Settlement 455, 461; FIFA kararı için ayrıca bkz: FIFA EXECUTIVE COMMITTEE: FIFA Executive Committee sets presidential election for 26 February 2016 and fully supports roadmap for reform (FIFA, 20 Jul 2015) <http://m.fifa.com/about-fifa/news/y=2015/m=7/news=fifaexecutive-committee-sets-presidential-electionfor-26-february-20-2666448.html> accessed 01 September 2021. 
insan hakları ve iş dünyası etkileşimi, hükümetlerin Rehber İlkeler’i göz önünde bulundurarak bir sosyal norm yaratmasında da araç olarak görülmektedir. Kurumsal sosyal sorumluluğu ön plana çıkaran eylemlerin desteklenmesinin ekonomik ve siyasi fayda sağlayacak olmasının yanı sıra, bu yaklaşım devlet ve iş ortaklıkları ilişkileri de gelişecektir. ${ }^{85}$

$\mathrm{Bu}$ doğrultuda uluslararası sistemdeki uygulayıcı görüşleri de önem kazanmaktadır. İş dünyası avukatları insan hakları konusunda yumuşak ve sert hukuk düzenlemelerinin kafa karıștırıcı olabildiğini, şirketlerin sert hukuka dönüşebilecek yumuşak hukuk düzenlemelerine artan oranda uyum gösterdiklerini, bununla birlikte yumuşak hukuk uygulamalarının şirketleri yükümlülükten muaf kılmadığını ifade etmektedir. İnsan haklarına ilişkin yumuşak hukuk uygulamaları şirketler için yasal düzenlemelerden öte bir kültür ve anlayış meselesine dönüşmektedir. ${ }^{86}$ Rehber İlkelerin uygulanması konusunda şirketlerle çalışan avukatlar öncelikli sorunun bağlayıcı olmayan ilkelere odaklanmanın gereği üzerine olduğunu belirtmektedir. Zamanla bu algının değiștiği, dünyanın birçok yerinde şirketlerin yasal olarak bağlayıcılığı olmasa da insan haklarını koruma ve iş dünyasını uyumlaştıran düzenlemelere yer verdikleri görülmektedir. Söz konusu yumuşak hukuk ilkeleri insan haklarına yüksek düzeyde ilgi göstermeyi gerektirmekte, şirketlerin insan hakları farkındalığını artırmakta, bu alandaki gelişmelere rehberlik etmekte ve insan hakları konularında şeffaflığı sağlamaktadır. Bununla birlikte şirketle ilişkili tüm aktörlerle etkileşimi artırmaktadır. ${ }^{87}$

Özellikle iş dünyasında insan haklarının önemini öne çıkaran algı değişikliğine vurgu yapan alan avukatlar, uluslararası ve bölgesel mahkemelerde, kamuoyunda değișen bu algıyla birlikte yumuşak hukukun yükselişini (d)evrimsel olarak nitelemektedir. Bu değişim ve dönüşüm özellikle yatırım antlaşması davalarında görülmektedir. Bu konudaki uyuşmazlıkların çözümü işleyişlerinde de geleneksel olmayan seçeneklere olan eğilim atmaktadır. ${ }^{88}$ Yasal kuruluşlar Rehber İlkeler'in uygulamadaki hukukla uyumlaştırılması konusunda rehberlik etme gayretinde olmuşlardır. Şirketlerin talepleri de bu doğrultuda artmıştır. Bu durum aynı zamanda yeni bir paradigma olarak da nitelenmiştir. Bu yeni eğilime karşılık hukuk şirketleri tarafından çok taraflı bu konuya ilişkin eğitim programları düzenlemek gibi değişime ayak uyduracak seçenekler de gündeme gelmektedir. ${ }^{89}$ Uygulayıcıların var olan durumun kabulüyle çözüm arayışına girmesi yumuşak hukukun varlığını güçlendirmektedir.

85 Noura Barakat, 'The U.N. Guiding Principles: Beyond Soft Law' (2016) 12(3) Hastings Business Law Journal, $591,613$.

86 NautaDutilh, 'Soft Law, sometimes harder' (NautaDutilh International Law Firm) <https://www.nautadutilh.com/en/ our-stories/the-next-generation/soft-law> accessed 03 September 2021.

87 Anna Triponel, 'When soft law is not so soft: The rapid legalisation of business and human rights' (Triponel Consulting, 14 October 2019) <https://triponelconsulting.com/2019/10/14/when-soft-law-is-not-so-soft-the-rapid-legalisation-ofbusiness-and-human-rights/> accessed 03 September 2021.

88 Stéphane Brabant and Marco de Sousa and Caitlin Eaton, 'Business and Human Rights: A (R)evolution of the Law?' (Herbert Smith Freehills 2021) <https://www.herbertsmithfreehills.com/latest-thinking/business-and-human-rights-arevolution-of-the-law> accessed 03 September 2021. Makaledeki ifade Türkçe’ye (d)evrimsel olarak çevrilmiştir.

89 White \& Case, 'Soft Law gets a hard look' (White\&Case Legal Education, 24 March 2017) <https://www.whitecase.com/ publications/story/soft-law-gets-hard-look> accessed 02 September 2021. 


\section{SONUÇ}

İş ilişkili insan hakları ihlallerinin kapsamlı bir biçimde ele alınmasının önünü açan BM Küresel İlkeleri ile birlikte BM İş Dünyası ve İnsan Hakları Rehber İlkeleri, bir yumuşak hukuk örneği olarak uluslararası hukukta yumuşak hukuka yöneltilen olumlu olumsuz eleştirilerden payını almıştır. Yumuşak hukuk ve sert hukuk ilişkisinde yumuşak hukukun bir antlaşma ya da yapılageliş sonucunda sert hukuka dönüşmesi yoluyla tamamlayıcılık göstermesi, karşı ögeler içererek birbirlerini dışlamaları ya da birbirleri yerine tercih edilmeleriyle seçenek oluşturmaları söz konusu olmaktadır. BM İş Dünyası ve İnsan Hakları Rehber İlkeleri örneğinde de yumuşak hukuka ilişkin tartışmalar bu kapsamda yürütülmüştür.

Bununla birlikte ilkelerin bağlayıcılığının olmaması, ilkelere uyum gösterilmediğinde, bir ihlal söz konusu olduğunda bir denetim işleyişi ya da öngörülen yasal bir yaptırımdan yoksun olması başlıca olumsuz eleştiriler arasında yer almaktadır.Yumuşak hukukun olumsuz yanlarına odaklanan eleştiriler, bir sert hukuk düzenlemesine ihtiyaç olduğunu belirterek bir uluslararası antlaşmanın yapılmasını savunmaktadır. Bu görüşler, ihlaller konusunda bir zorlayıcılık ögesinin bulunmamasının Rehber İlkeleri’ni zayıflattığı savıyla desteklenmektedir. Bu nedenle bu görüşlere göre Rehber İlkeleri sınırlı bir etkiye sahiptir ve ihlaller karşısında sorumlu tutma konusunda başarısızdır.

İncelenen düzenlemelerde devlet ve şirketlerin ayrı konumları, ortaklaşa sorumluluk kavramının belirsizliğini de beraberinde getirmiş iki aktör arasında bir ikilem oluştuğu yönündeki görüşleri güçlendirmiştir. Bir uluslararası antlaşma yapılmasının önündeki önemli engellerden biri bu karmaşık yapıdır. Rehber İlkeleri’nin sert hukuka dönüşmesinin gerekli olmadığını savunanlar tarafından öne çıkarılan en önemli sonuç insan hakları ve iş dünyası konusunda güçlü bir farkındalığın sağlanmış olmasidir.

Genel olarak uluslararası hukuk özelde insan hakları hukuku ve iş dünyasıyla ilişkili alanlar açısından da oldukça önem taşıyan bu tartışmalarla birlikte çalışmada da COVID 19 süreciyle örneklendiği üzere güncelliğini koruyan konuların kesişim noktalarını artırdığı görülmektedir. Uluslararası alanda sınırları belirsizleşen konuların, tanım ve kapsam belirlemesinde zorluk yaşanan kavramların, devlet dışı aktörlerin varlık gösterdikleri alanların ve devlet temelli hukukun ötesine geçilmesi tartışmalarının artış göstermesiyle yumuşak hukuk ve sert hukuk ilişkisine ve bu ilişkinin kesişim noktalarında yer alan konulara dair daha çok çalışma yapılmasının gerektiği değerlendirilmektedir. Yumuşak hukuk tartışmaları çerçevesinde BM İş Dünyası ve İnsan Hakları Rehber İlkeleri örneği, yumuşak hukukun uluslararası hukuktaki zorlu konumunu göstermekle birlikte gelecekte de varlığını etkin bir biçimde sürdüreceğine işaret etmektedir.

\section{KAYNAKÇA}

Addo MK, 'Is Business and Human Rights Suitable for the Compliance Function?' (7 January 2020) The

University of Chicago Law Review Online <https://lawreviewblog.uchicago.edu/2020/01/07/isbusiness-and-human-rights-suitable-for-the-compliance-function-by-michael-k-addo/ > accessed 10 August 2021. 
Abbott KW and Duncan S, 'Hard and Soft Law in International Governance' (2000) 54 International Organization 421-456.

Backer LC, 'Moving Forward the UN Guiding Principles for Business and Human Rights: Between Enterprise Social Norm, State Domestic Legal Orders, and the Treaty Law That Might Bind Them All' (2015) 38(2) Fordham International Law Journal 457-542.

Barakat N, 'The U.N. Guiding Principles: Beyond Soft Law' (2016) 12(3) Hastings Business Law Journal, 591613.

Betts A, 'Towards a 'soft law' Framework for the Protection of Vulnerable Migrants' (2008) 13 (162) New Issues in Refugee Research (Policy Development and Evaluation Service, United Nations High Commissioner for Refugees) 1-26.

Blutman L, 'In the Trap of a Legal Metaphor: International Soft Law' (2010) 59 International and Comparative Law Quarterly 605-624.

Bialek J, 'Evaluating the Zero Draft on a UN Treaty on Business and Human Rights: What Does it Regulate and how Likely is its Adoption by States?' (2019) (9) Goettingen Journal of International Law 501-536.

Bodonsky D, 'The Art and Craft of International Environmental Law' (Harvard University Press 2011).

Boyle AE, 'Some Reflections on the Relationship of Treaties and Soft Law' (1999) 48(4) International and Comparative Law Quarterly 901-913.

Boyle AE and Chinkin C, 'The Making of International Law' (Oxford University Press 2007).

Brabant S and Sousa M and Eaton C, 'Business and Human Rights: A (R)evolution of the Law?' (Herbert Smith Freehills 2021) <https:/www.herbertsmithfreehills.com/latest-thinking/business-and-human-rights-arevolution-of-the-law $>$ accessed 03 September 2021.

Broek OV, 'Soft Law Engagements and Hard Law Preferences: Comparing EU Lobbying Positions between UN Global Compact Signatory Firms and Other Interest Group Types' (2021) 23 Business and Politics 383405 .

Cassel D, 'Does the World Need a Treaty on Business and Human Rights? Weighing the Pros and Cons' (Notre Dame Law School Notre Dame London Centre 14 May 2014).

Choudhury B, 'Balancing Soft and Hard Law for Business and Human Rights' (2018) 67(4) International and Comparative Law Quarterly 961-986.

Cirlig RE, 'Business and human rights: from soft law to hard law?' (2016) 6(2) 228-246.

European Parliament, Directorate-General for External Policies, Policy Department, 'Implementation of the UN Guiding Principles on Business and Human Rights' (February 2017) EP Doc EP/EXPO/B/ COMMITTEE/FWC/2013-08/Lot8/09, doi:10.2861/29813

Fastenrath U, 'Relative Normativity in International Law' (1993) 4(1) European Journal of International Law, 324-339.

Gabriel HD, 'The Advantages of International Commercial Law: The Role of UNIDROIT, UNCITRAL and The Hague Conference' (2009) 34(3) Brooklyn Journal of International Law 655-672.

Ghafele R and Mercer A, 'Not Starting in Sixth Gear': An Assesment of the UN Global Compact's Use of Soft Law as a Global Governance Structure for Corporate Social Responsibility' (2011) 17(1) U.C. Davis J. Int'l L. \& Pol'y 41-60.

Goldmann M, 'We Need to Cut Off theHead of the King: Past, Present, and Future Approaches to International Soft Law' (2012) 25 335-368.

Grant JP and Barker JC, Encyclopaedic Dictionary of International Law (Oxford University Press 2009).

Grnchalla-Wesierski T, 'A Framework for “Understanding Soft Law' (1984) 30 McGill Law Journal 37-88. 
Guruparan K and Zerk J, 'Influence of soft law grows in International governance' (Chatham House, The Royal Institute of International Affairs, 17 June 2021) <https://www.chathamhouse.org/2021/06/influencesoft-law-grows-international-governance> accessed 02 September 2021.

Guzman AT, 'The Design of International Agreements' (2005) 16(4) The European Journal of International Law 583-591.

Hamm B, 'The Struggle for Legitimacy in Business and Human Rights Regulation-a Consideration of the Processes Leading to the UN Guiding Principles and an International Treaty' (2021) Human Rights Review.

Hurwitz AG, 'The Collective Responsibility of States to Protect Refugees' (Oxford University Press 2009).

International Labour Organization, 'ILO Conventions and Recommendations' (ILO) <http://www.ilo.org/ global/standards/introduction-to-international-labour-standards/conventions-and-recommendations/ lang_en/index.htm> accessed 10 July 2021

International Organisation of Employers (IOE), '\#UNGPsPlus10, Achievements, challenges, and the way forward in the uptake and implementation of the UN Guiding Principles on Business and Human Rights' (European Union February 2021).

İlhami Alkan Olsson, 'Four Competing Approaches to International Soft Law' (2013) 58 Scandinavian Studies in Law 177-196.

Keller H, 'Codes of Conduct and their Implementation: the Question of Legitimacy' in Rüdiger Wolfrum and Volker Röben (eds) Legitimacy in International Law (Max-Planck Institut, Springer 2008).

Klabbers J, 'The Redundancy of Soft Law' (1996) 65(2) Nordisk Journal of International Law 167-182.

Klabbers J, 'Reflections on Soft International Law in a Privatized World' in Jan Klabbers (ed), Finnish Yearbook of International Law c. XVI (Leiden: Koninklijke Brill NV 2008) 313-328.

Lindsay R, Kirkpatrick A and Low JE, 'Hardly Soft Law: The Modern Slavery Act 2015 and the Trend Towards Mandatory Reporting on Human Rights' (2017) 18(1) Business Law International 29-50.

Marochkin S and Khalafyan R, 'The Norms of International Soft Law in the Legal System of the Russian Federation' (2013) 6(2) Journal of Politics and Law 90-104.

Matsushita M, 'A View on Future Roles of The WTO: Should There be More Soft Law in The WTO?' (2014) 17 Journal of International Economic Law 701-715.

Meyer T, 'Soft Law as Delegation' (2009) 32 Fordham Int'l L.J. 888-940.

NautaDutilh, 'Soft Law, sometimes harder' (NautaDutilh International Law Firm) <https://www.nautadutilh. com/en/our-stories/the-next-generation/soft-law> accessed 03 September 2021.

Neuhold H, 'The Inadequacy of Law Making by International Treaties: Soft Law as an Alternative?' in Rüdiger Wolfrum and Volker Röben (eds) Developments of International Law in Treaty Making (Springer 2005).

Office of the United Nations High Commissioner for Human Rights (OHCHR), 'Human Rights Translated: A business Reference Guide’ (Castan Centre for Human Rights Law, International Business Leaders Forum and Office of the United Nations High Commissioner for Human Rights 2008).

OHCHR 'Responsibilities of transnational corporations and other business enterprises with regard to human rights' (2003) UN Doc E/CN.4/Sub.2/RES/2003/16.

OHCHR 'Responsibilities of transnational corporations and related business enterprises with regard to human rights' (22 April 2004) UN Doc E/CN.4/DEC/2004/116

OHCHR 'Human rights and transnational corporations and other business enterprises-Human Rights Resolution’ (20 April 2005) UN Doc E/CN.4/RES/2005/69 
OHCHR 'Human Rights at the Heart of Response, Business and Human Rights in times of COVID-19' (October 2020) UN Doc https://www.ohchr.org/Documents/Issues/Business/BusinessAndHR-COVID19.pdf accessed 25 August 2021.

Parella K, 'Hard and Soft Law Preferences in Business and Human Rights' (2020) 114 AJIL Unbound 168-173.

Paulo S and Reisen H, 'Eastern Donors and Western Soft Law: Towards a DAC Donor Peer Review of China and India?' (2010) 25(5) Development Policy Review 535-552.

Raustiala K, 'Form and Substance in International Agreements' (2005) 99(58) The American Journal of International Law 581-614.

Robilant AD, 'Genealogies of Soft Law' (2006) 54(3) The American Journal of Comparative Law 499-554.

Ruggie JG, 'Business and Human Rights: The Evolving International Agenda' (2007) 101(4) The American Journal of International Law 819-840.

Ruggie JG and Sherman JF, 'Adding Human Rights Punch to the New Lex Mercatoria : The Impact of the UN Guiding Principles on Business and Human Rights on Commercial Legal Practice' (2015) 6(3) Journal of International Dispute Settlement 455-461.

Ruggie JG, 'Social Norms, Soft Law, Hard Law: The Evolution of Business and Human Rights', (The Castan Centre for Human Rights Law, Monash Business School and Global Compact Network Australia, Public Lecture, Docklands, 30 April 2019) <https://www.monash.edu/law/research/centres/castancentre/ public-events/events/2019/social-norms,-soft-law,-hard-law-the-evolution-of-business-and-humanrights $>$ accessed 02 September 2021.

Schutter O, 'Towards a New Treaty on Business and Human Rights' (2015) 1 Business and Human Rights Journal 41-67.

Shaffer GC and Pollack MA, 'Hard Versus Soft Law in International Security' (2011) 52(4) Boston Collage Law Review 1147-1167.

Shaffer GC and Pollack MA, 'Hard vs. Soft Law: Alternatives, Complements and Antogonists in International Governance' (2010) 9 (23) University of Minnesota Law School Legal Studies Research Paper Series 706-799.

Schäfer A, 'Resolving Deadlock: Why International Organisations Introduce Soft Law' (2006) 12(2) European Law Journal 194-208.

Shaw MN, 'International Law' (Cambridge University Press 2008).

Shelton DL, 'Encyclopedia of Genocide and Crimes Against Humanity' (Thomson Gale, 2005) 567; Finn Seyersted, Common Law of International Organizations ( Nijhoff 2008).

Shift, Oxfam and Global Compact Network Hollanda, 'İnsan Haklarına Saygılı İş Yapma: Şirketlere Yönelik Kilavuz' (2016).

Simma B, 'Consent, Strains in the Treaty System' in Ronald St. J. Macdonald and Douglas M. Johnston (eds) The Structure and Process of International Law: Essays in Legal Philosophy Doctrine and Theory (Martinus Nijhoff 1983).

Triponel A, 'When soft law is not so soft: The rapid legalisation of business and human rights' (Triponel Consulting, 14 October 2019) <https://triponelconsulting.com/2019/10/14/when-soft-law-is-not-sosoft-the-rapid-legalisation-of-business-and-human-rights/> accessed 03 September 2021.

Trubek DM and Trubek LG, 'Hard and Soft Law in the Construction of Social Europe: the Role of the Open Method of Co-ordination' (2005) 11(3) European Law Journal 343-364.

United Nations Economic and Social Council 'Norms on the responsibilities of transnational corporations and other business enterprises with regard to human rights' (26 August 2003) UN Doc E/CN.4/ Sub.2/2003/12/Rev.2 
United Nations General Assembly, 'Universal Declaration of Human Rights, General Assembly resolution 217 A (III) of 10 December 1948' (OHCHR) https://www.ohchr.org/Documents/Publications/ FactSheet2Rev.1en.pdf

UNGA, 'Towards global partnerships: a principle-based approach to enhanced cooperation between the United Nations and all relevant partners' (7 February 2014) UN Doc A/RES/68/234

United Nations Global Compact, 'What is the UN Global Compact' <https://www.unglobalcompact.org/whatis-gc/mission> accessed 05 July 2021; Ayrıca bknz: UN Global Compact Network Türkiye, 'Hakkımızda', https://www.globalcompactturkiye.org/un-global-compact/ Erişim Tarihi: 05 Temmuz 2021.

UN Global Compact Office, 'The Global Compact Brochure’ (United Nations 2004).

UN Global Compact, "Guidance on Responsible Business in Conflict-Affected and High-Risk Areas: A Resource for Companies and Investors", UN Global Compact Office-PRI Publication, 2010.

UN Global Compact, Annie Golden Bersagel, "Meeting the Responsibility to Respect in Situations of Conflicting Legal Requirements", A Good Practice Note endorsed by the United Nations Global Compact Human Rights Working Group on 13 June 2011.

UN Global Compact and OCHR, 'A Guide for Business: How to Develop a Human Rights Policy', (United Nations Global Compact Office and Office of the United Nations High Commissioner for Human Rights, 2015).

UN Global Compact, 'The Ten Principles of the UN Global Compact, Principle One: Human Rights' (UN Global Compact) <https://www.unglobalcompact.org/what-is-gc/mission/principles/principle-1> accessed 02 August 2021.

UN Global Compact, 'The Ten Principles of the UN Global Compact, Principle Two: Human Rights' (UN Global Compact) <https://www.unglobalcompact.org/what-is-gc/mission/principles/principle-2> accessed 02 August 2021.

UNGlobalCompact, 'UN GlobalCompactStrategy 2021-2023' (19January2021)<https://ungc-communicationsassets.s3.amazonaws.com/docs/about_the_gc/UN-GLOBAL-COMPACT-STRATEGY-2021-2023.pdf> accessed 20 August 2021.

UN Global Compact, ‘\#UnitingBusiness to Respond to COVID 19’<https://www.unglobalcompact.org/takeaction/20th-anniversary-campaign/uniting-business-to-tackle-covid-19> accessed 21 August 2021.

United Nations, 'Global Compact Summit Concludes with Emphasis on Need to Fight Corruption, Global Compact Leaders Summit Press Release' (24 June 2004) UN Doc ECO/70

United Nations Human Rights Council (UNHRC) 'Mandate of the Special Representative of the Secretary General on the issue of human rights and transnational corporations and other business enterprises' (18 June 2008) UN Doc A/HRC/RES/8/7

UNHRC 'Report of the Special Representative of the SecretaryGeneral on the issue of human rights and transnational corporations and other business enterprises, John Ruggie, Guiding Principles on Business and Human Rights: Implementing the United Nations "Protect, Respect and Remedy" Framework' (21 March 2011) UN Doc A/HRC/17/31

UNHRC 'Human rights and transnational corporations and other business enterprises' (06 July 2011) UN Doc $\mathrm{A} / \mathrm{HRC} / \mathrm{RES} / 17 / 4$

UNHRC 'Contribution of the United Nations system as a whole to the advancement of the business and human rights agenda and the dissemination and implementation of the Guiding Principles on Business and Human Rights' (16 October 2012) UN Doc A/HRC/RES/21/5

UNHRC 'Elaboration of an international legally binding instrument on transnational corporations and other business enterprises with respect to human rights' (14 July 2014) UN Doc A/HRC/RES/26/9 
UNHRC 'Human rights and transnational corporations and other business enterprises' (15 July 2014) UN Doc $\mathrm{A} / \mathrm{HRC} / \mathrm{RES} / 26 / 22$

UNHRC 'Business and human rights: improving accountability and access to remedy' (15 July 2016) UN Doc $\mathrm{A} / \mathrm{HRC} / \mathrm{RES} / 32 / 10$

UNHRC 'Business and human rights: mandate of the Working Group on the issue of human rights and transnational corporations and other business enterprises' (14 July 2017) UN Doc A/HRC/RES/35/7

UNHRC 'Business and human rights: improving accountability and access to remedy' (18 July 2018) UN Doc $\mathrm{A} / \mathrm{HRC} / \mathrm{RES} / 38 / 13$

UNHRC 'Business and human rights: the Working Group on the issue of human rights and transnational corporations and other business enterprises, and improving accountability and access to remedy' (23 July 2020) UN Doc A/HRC/RES/44/15

United Nations 'Secretary-General Proposes Global Compact on Human Rights, Labaour, Environment, in Address to World Economic Forum in Davos, Press Release' (1 February 1999) UN Doc SG/SM/6881

United Nations Security Council Resolution 1446 (2002) (4 December 2002) UN Doc S/RES/1446

UNSC Resolution 1459 (2003) (28 January 2003) UN Doc S/RES/1459

UNSC Resolution 1472 (2003) (28 March 2003) UN Doc S/RES/1472

United Nations, 'Transcript of Press Conference by Secretary-General Kofi Annan at Headquarters' (26 July 2000) UN Doc SG/SM/7496

White \& Case, 'Soft Law gets a hard look' (White\&Case Legal Education, 24 March 2017) <https://www. whitecase.com/publications/story/soft-law-gets-hard-look> accessed 02 September 2021.

Williamson JrRL, 'Hard Law, Soft Law, and Non-Law in Multilateral Arms Control: Some Compliance Hypotheses' (2003) 4(1) 5982. 